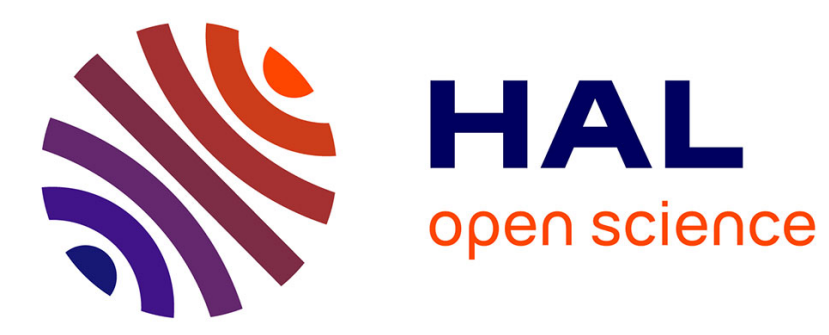

\title{
Short-term effects of biochar on soil CO2 efflux in boreal Scots pine forests
}

Xudan Zhu, Tingting Zhu, Jukka Pumpanen, Marjo Palviainen, Xuan Zhou, Liisa Kulmala, Viktor J. Bruckman, Egle Köster, Kajar Köster, Heidi Aaltonen, et al.

\section{To cite this version:}

Xudan Zhu, Tingting Zhu, Jukka Pumpanen, Marjo Palviainen, Xuan Zhou, et al.. Short-term effects of biochar on soil CO2 efflux in boreal Scots pine forests. Annals of Forest Science, 2020, 77 (2), pp.59. 10.1007/s13595-020-00960-2 . hal-03265521

\section{HAL Id: hal-03265521 \\ https://hal.science/hal-03265521}

Submitted on 21 Jun 2021

HAL is a multi-disciplinary open access archive for the deposit and dissemination of scientific research documents, whether they are published or not. The documents may come from teaching and research institutions in France or abroad, or from public or private research centers.
L'archive ouverte pluridisciplinaire HAL, est destinée au dépôt et à la diffusion de documents scientifiques de niveau recherche, publiés ou non, émanant des établissements d'enseignement et de recherche français ou étrangers, des laboratoires publics ou privés. 


\title{
Short-term effects of biochar on soil $\mathrm{CO}_{2}$ efflux in boreal Scots pine forests
}

\author{
Xudan Zhu ${ }^{1}$ (D) - Tingting Zhu ${ }^{2}$ - Jukka Pumpanen ${ }^{3} \cdot$ Marjo Palviainen $^{4} \cdot$ Xuan Zhou $^{4} \cdot$ Liisa Kulmala ${ }^{4}$. \\ Viktor J. Bruckman ${ }^{5}$. Egle Köster ${ }^{4} \cdot$ Kajar Köster $^{4,6} \cdot$ Heidi Aaltonen ${ }^{4}$. Naoki Makita ${ }^{4,7} \cdot$ Yixiang Wang $^{2}$. \\ Frank Berninger ${ }^{1}$
}

Received: 2 June 2019 / Accepted: 11 May 2020 / Published online: 15 June 2020

(C) The Author(s) 2020

\begin{abstract}
- Key message During the first summer, wood biochar amendments increased soil temperature, $\mathrm{pH}$, and soil $\mathrm{CO}_{2}$ effluxes in a xeric boreal Scots pine forest. The increase of soil $\mathrm{CO}_{2}$ efflux could be largely explained by increases in by soil temperature. Higher biochar application rates $\left(1.0 \mathrm{vs} 0.5 \mathrm{~kg} \mathrm{~m}^{-2}\right)$ led to higher soil $\mathrm{CO}_{2}$ efflux while the pyrolysis temperature of biochar $\left(500\right.$ or $\left.650{ }^{\circ} \mathrm{C}\right)$ had no effect on soil $\mathrm{CO}_{2}$ efflux.

- Context Using biochar as a soil amendment has been proposed to increase the carbon sequestration in soils. However, a more rapid soil organic matter turnover after biochar application might reduce the effectiveness of biochar applications for carbon sequestration. By raising the pyrolysis temperature, biochar with lower contents of labile carbohydrates can be produced.

- Aims To better understand the effects of biochar on boreal forest soil, we applied two spruce biochar with different pyrolysis temperatures $\left(500{ }^{\circ} \mathrm{C}\right.$ and $\left.650{ }^{\circ} \mathrm{C}\right)$ at amounts of 1.0 and $0.5 \mathrm{~kg} \mathrm{~m}^{-2}$ in a young xeric Scots pine forest in southern Finland.

- Methods Soil $\mathrm{CO}_{2}$, microbial biomass, and physiochemical properties were measured to track changes after biochar application during the first summer.

- Results Soil $\mathrm{CO}_{2}$ increased $14.3 \%$ in $1.0 \mathrm{~kg} \mathrm{~m}^{-2}$ treatments and $4.6 \%$ in $0.5 \mathrm{~kg} \mathrm{~m}^{-2}$. Soil temperature and $\mathrm{pH}$ were obviously higher in the $1.0 \mathrm{~kg} \mathrm{~m}^{-2}$ treatments. Differences in soil $\mathrm{CO}_{2}$ among treatments disappear after correcting by soil temperature and soil moisture.
\end{abstract}

\section{Handling Editor: Ana Rincón}

Contributions of the co-authors Xudan Zhu: Field and lab work, data analysis, methodology, writing of the original draft, submission, revision Tingting Zhu: Field and lab work, writing of the original draft partly, revision

Frank Berninger: Supervision, conceptualization, methodology, validation, revision

Jukka Pumpanen: Methodology, revision, validation, funding acquisition Marjo Palviainen: Experiment setup, field work, methodology, revision

Xuan Zhou: Data analysis, draw graphs, revision

Liisa Kulmalab: Data analysis, revision

Viktor J. Bruckmane: Organization of the biochar from Austria, revision

Egle Kösterb: Experiment setup, revision

Kajar Köster: Experiment setup, revision

Naoki Makita: Experiment setup, revision

Heidi Aaltonen: Experiment setup, revision

Yixiang Wang: Funding support from China, revision

Xudan Zhu

xudanzhu@uef.fi

Extended author information available on the last page of the article 
- Conclusion Biochar increased soil $\mathrm{CO}_{2}$ mainly by raising soil temperature in the short term. Higher biochar application rates led to higher soil $\mathrm{CO}_{2}$ effluxes. The increase in soil $\mathrm{CO}_{2}$ efflux may be transient. More studies are needed to get the optimum biochar amount for carbon sequestration in boreal forest.

Keywords Biochar $\cdot$ Soil microbial biomass $\cdot$ Soil $\mathrm{CO}_{2} \cdot$ Soil temperature $\cdot$ Boreal forest

\section{Introduction}

Biochar is a C-rich material produced by pyrolyzing biomass or other organic materials, such as agricultural crop residues, wood, and green waste in an oxygen-depleted environment (Ahmed and Schoenau 2015). In 2001, the term "biochar" was coined after Glaeser describing "Terra preta" soils (Glaser et al. 2001). It is used as a soil amendment to increase productivity, restore soil fertility, sequester $\mathrm{C}$ in soil, and reduce atmospheric $\mathrm{CO}_{2}$ concentration (Woolf 2008; Van Zwieten et al. 2010; Wang et al. 2014). Its aromatic structures make it resistant to microbial decomposition (Kumar et al. 2005; Schimmelpfennig and Glaser 2012). Since that, the majority of studies on the effects of biochar application on soils have been on agricultural soils (Prayogo et al. 2014; Lu et al. 2014; Zhang et al. 2017). Contrary to agricultural ecosystems, the effects of newly added biochar on forest ecosystems are still uncertain.

Previous studies on the effects of biochar addition on soil $\mathrm{CO}_{2}$ effluxes in subtropical and temperate forests show inconsistent results. Some studies show that $\mathrm{CO}_{2}$ fluxes increase (Mitchell et al. 2015; Bamminger et al. 2016; Hawthorne et al. 2017; Johnson et al. 2017); others indicate a decrease in fluxes; and some do not show any effect of biochar. Studies on the effects of large-scale biochar application in boreal forests are rare.

Biochar increase $\mathrm{N}$ uptake by some plant species (Wardle et al. 1998), increase nutrient availability (Glaser et al. 2001), and enhance humus formation (Glaser et al. 2001). Therefore, it may mitigate the negative effects of biomass harvesting in Nlimited boreal forests. Biochar can also act as a soil conditioner; it enhances plant growth by improving soil aggregation, soil porosity, cation-exchange capacity, and $\mathrm{pH}$ (Biederman and Harpole 2013; Thomas and Gale 2015; Li et al. 2018) and by adsorbing toxic compounds (Wardle et al. 1998; Robertson et al. 2012). These changes in soil physiochemical properties may affect soil $\mathrm{CO}_{2}$ emissions (Peng and Thomas 2010) by altering soil microbial diversity and activity and by changing fine root production and root respiration (He et al. 2017). Moreover, previous studies have found that the labile $\mathrm{C}$ fractions of biochar may accelerate the decomposition of native soil organic matter in a process known as the "positive priming effect" (Luo et al. 2013; Maestrini et al. 2015; Fang et al. 2015; Wang et al. 2016). In addition, Zackrisson et al. (1996) and Wardle et al. (1998, 2008) indicated that fire-derived charcoal can adsorb phenolic compounds and accelerate organic matter decomposition in boreal forests. On the other hand, a negative priming effect can also occur due to the fact that biochar can (i) absorb labile $\mathrm{C}$, reducing its availability to soil microorganisms (Jones et al. 2012), (ii) absorb enzymes involved in the decomposition of soil organic matter and thus decrease their activity (Woolf and Lehmann 2012), and (iii) directly absorb soil $\mathrm{CO}_{2}$ ( $\mathrm{Li}$ et al. 2018).

$\mathrm{An}$ increase in soil $\mathrm{CO}_{2}$ efflux at the initial stage after biochar incorporation has been reported, which may be due to the rapid decomposition of the labile component of $\mathrm{C}$ in the biochar (Cross and Sohi 2011; Luo et al. 2011; Ouyang et al. 2014), accelerated decomposition of native soil $C$ induced by the biochar (Singh and Cowie 2015; Bruckman et al. 2015; Wang et al. 2016), or the increasing soil temperature (biochar addition decreases the soil surface albedo) (Genesio et al. 2012). These impacts of biochar addition on soil depend on soil properties (Kolb et al. 2009; Spokas et al. 2009), vegetation, and local environmental and climatic conditions (He et al. 2018). Biochar-induced increases in soil $\mathrm{CO}_{2}$ fluxes have been shown to increase with latitude and have been attributed to increased soil temperature after biochar addition and the larger stimulation of microbial activity in highlatitude, temperature-limited ecosystems (He et al. 2017). In addition, different feedstocks and pyrolysis temperatures will result in differences of biochar physical and chemical properties. In general, wood biochar increases soil $\mathrm{CO}_{2}$ efflux to a lesser degree compared with other types of biochar (Zimmerman et al. 2011; He et al. 2017). Furthermore, by raising the pyrolysis temperature, biochar with none or low contents of unconverted cellulosic and hemicellulosic fractions can be produced, as these labile carbohydrates are rapidly mineralized; their presence lowers the biocharC sequestration potential (Bruun et al. 2011). Ameloot et al. (2013) found $\mathrm{CO}_{2}$ emissions were significantly higher in $350{ }^{\circ} \mathrm{C}$ biochar treatments than control, while no significant difference in $700{ }^{\circ} \mathrm{C}$ biochar treatments. Fang et al. (2015) showed that $550^{\circ} \mathrm{C}$ wood biochar was more effective for long-term soil C storage relative to $450{ }^{\circ} \mathrm{C}$ wood biochar. Meanwhile, the dosage of biochar may also affect the responses in soil respiration. Previous studies have shown increased soil $\mathrm{CO}_{2}$ effluxes with increasing biochar application rates in temperate forests (Mitchell et al. 2015), while meta-analyses from agricultural soils have only shown increases of soil $\mathrm{CO}_{2}$ effluxes at high (2$4 \mathrm{~kg} \mathrm{~m}^{-2}$ ) amendment rates (Song et al. 2016; He et al. 2017). In boreal forests, the effects of biochar on soil $\mathrm{CO}_{2}$ efflux are rarely studied. Gundale et al. (2016) applied $1-\mathrm{kg} \mathrm{m}^{-2}$ biochar to soil by mixing it into the soil after clear-cutting and stump harvesting and observed no changes in soil respiration suggesting its good stability against decomposition. Due to increasing concern for carbon loss, impacts on water and biodiversity, less invasive forest regeneration practices are getting more attention as 
an alternative to clear-cutting which has so far been the most common method of forest harvesting in boreal forests. In the future, the harvesting techniques where part of the trees are left standing and the soil surface is not mixed after the harvesting are probably becoming more common. However, there is little information on the effects of biochar treatments on intact forest soils in boreal forests.

In this study, commercially available biochar produced from Norway spruce (Picea abies (L.) H. Karst) woodchips by controlled pyrolysis at $500{ }^{\circ} \mathrm{C}$ and $650{ }^{\circ} \mathrm{C}$ was used at two typically and economically feasible amounts $\left(0.5\right.$ and $\left.1.0 \mathrm{~kg} \mathrm{~m}^{-2}\right)$ on intact forest soil (see e.g. Bruckman et al. 2015; Gundale et al. 2016). The aim of this study was to determine (1) whether biochar addition changes soil respiration, soil temperature, soil moisture, soil $\mathrm{pH}$, and microbial biomass during the initial 5 months after application on boreal Scots pine (Pinus sylvestris L.) forest stands; and (2) whether the pyrolysis temperature and amount of biochar affect these aforementioned factors. We hypothesized that biochar amendment will increase soil $\mathrm{CO}_{2}$ efflux by changing the soil physiochemical and biological properties at the initial stage and higher efflux is expected at higher biochar application rates (1 vs $0.5 \mathrm{~kg} \mathrm{~m}^{-2}$ ). Besides, as biochar with lower contents of labile carbohydrates can be produced by rising the pyrolysis temperature, lower soil $\mathrm{CO}_{2}$ efflux is anticipated when biochar pyrolyzed at higher temperatures $\left(650^{\circ} \mathrm{C}\right.$ vs $\left.500^{\circ} \mathrm{C}\right)$ is applied to soil.

\section{Material and methods}

\subsection{Site description}

The field experiment was performed during the summer of 2015 in Juupajoki $\left(61^{\circ} 48^{\prime} \mathrm{N}\right.$ and $24^{\circ} 18^{\prime} \mathrm{E}, 181 \mathrm{~m}$ a.s.l.) close to the Hyytialä Forestry Field Station in southern Finland. The experiment was established in young approximately 20 -year-old Scots pine (Pinus sylvestris L.) forest stands that were naturally regenerated from seed trees after harvesting. These trees belong to the Vaccinium- and Calluna-type forests according to the Finnish site-type classification (Cajander 1949). All plots are common low-fertility xeric site types. Vaccinium vitis-idaea L., Calluna vulgaris (L.) Hull., Empetrum nigrum L., and V. myrtillus L. were the dominant species of the understorey vegetation. The forest floor was covered with mosses (Pleurozium schreberi (Brid.) Mitt., Hylocomium splendens (Hedw.) Schimp.) and some lichens (Cladina sp.). The soil is a nutrient-poor, well-drained haplic podzol (IUSS Working Group WRB, FAO 2015), and the soil texture is coarse sand (Table 1). The long-term (1981-2010) mean annual air temperature in the area is $3.5^{\circ} \mathrm{C}$, the mean annual precipitation is $700 \mathrm{~mm}$, and the snow cover duration is 145160 days (Pirinen et al. 2012). During the experimental period (May-September 2015), the mean temperature of the area was + $12.1^{\circ} \mathrm{C}$; May was the coldest month (mean $+8.6^{\circ} \mathrm{C}$ ) and August was the warmest (mean $+16.2{ }^{\circ} \mathrm{C}$ ). The mean monthly precipitation during the experiment was $67 \mathrm{~mm}$. Mean precipitation was highest in July (118 mm) and lowest in August (18 mm). The main characteristics of study plots in May before biochar application are shown in Table 1.

\subsection{Experimental design and measurement}

\subsubsection{Experimental setup}

The experiment was set up as a randomized block design with four replicates (called blocks) and five plots $(15 \mathrm{~m} \times 15 \mathrm{~m}$ rectangles) within each block (Zhu et al. 2020). To avoid pseudoreplication, blocks were separated by a few hundred meters from each other and belong to four different forest stands within a radius of $1.5 \mathrm{~km}$. The terrain of the blocks is flat with no slope. Within each block, we delimited suitable homogenous areas. The distance between each plot was $10 \mathrm{~m}$, and a 2.5 -m wide buffer zone surrounding plot edges was not used for measurements. Treatments were assigned randomly to plots in each block. Biochar (hereafter BC500 and BC650) used in the study were produced from Norway spruce (Picea abies (L.) H. Karst) wood chips at $500{ }^{\circ} \mathrm{C}$ and $650{ }^{\circ} \mathrm{C}$, respectively (manufactured by Sonnenerde $\mathrm{GmbH}$, Riedlingsdorf, Austria). The grain size was 5-10 mm. Both types of biochar were applied on the plots at two different rates $\left(0.5 \mathrm{~kg} \mathrm{~m}^{-2}\right.$ and $\left.1.0 \mathrm{~kg} \mathrm{~m}^{-2}\right)$. For simplicity, we will use abbreviated treatment names; e.g., T500M1.0 will denote plots that were amended with biochar produced at $500{ }^{\circ} \mathrm{C}$ at a rate of $1.0 \mathrm{~kg} \mathrm{~m}^{2}$. Thus, the five treatments were T500M0.5, T500M1.0, T650M0.5, T650M1.0, and control (without biochar amendment). The biochar was spread manually on top of the humus layer $(0.5-2.0 \mathrm{~cm})$ in May 2015 to avoid soil disturbance and damage to roots. During our experimental period, biochar remained on the surface of soil, but the moss-dominated vegetation did not suffer from biochar addition and remained stable. The mosses did not cover the biochar until the second summer after treatment (Palviainen et al. 2018).

\subsubsection{Soil and biochar physicochemical properties}

Soil samples were collected from the organic layer and the upper $15 \mathrm{~cm}$ of the mineral soil layer using a stainless soil corer (diameter $5.5 \mathrm{~cm}$ ) at nine randomly selected locations in each treatment in May, August, and September. The samples were divided into subsamples for the organic layer and mineral soil depths of 0 $5 \mathrm{~cm}$ and $5-15 \mathrm{~cm}$. To determine the chemical characteristics of the biochar, two biochar samples were collected from four biochar bags used for transporting the biochar from the factory to the experimental sites. Prior to analysis, soil and biochar samples were dried $\left(60^{\circ} \mathrm{C}, 24 \mathrm{~h}\right)$ and ground; soil was sieved through a 2-mm sieve to remove visible stones, coarse roots, and leaves before grinding. Subsamples were dried at $105^{\circ} \mathrm{C}$ to determine the dry mass of the sample. The $\mathrm{C}$ and $\mathrm{N}$ concentrations of soil and biochar were analyzed from the homogenized samples with 
Table 1 Main characteristics of treatment plots before biochar application in May. T500M1.0 denotes plots that were amended with biochar produced at $500{ }^{\circ} \mathrm{C}$ at a rate of $1.0 \mathrm{~kg} \mathrm{~m}^{2}$; T500M0.5 denotes plots that were amended with biochar produced at $500{ }^{\circ} \mathrm{C}$ at a rate of $0.5 \mathrm{~kg} \mathrm{~m}^{2}$; T650M1.0 denotes plots that were amended with biochar produced at $650{ }^{\circ} \mathrm{C}$ at a rate of $1.0 \mathrm{~kg} \mathrm{~m}^{2}$; T650M0.5 denotes plots that were amended with biochar produced at $650{ }^{\circ} \mathrm{C}$ at a rate of $0.5 \mathrm{~kg} \mathrm{~m}^{2}$; and control denotes plots without biochar amendment. Comparison among treatment plots was done by one-way ANOVA. The same letters indicate no statistically significant differences among treatments $(n=4, P<0.05)$. Values are mean $\pm \mathrm{SE}$

\begin{tabular}{|c|c|c|c|c|c|}
\hline & T500M0.5 & T500M1.0 & T650M0.5 & T650M1.0 & Control \\
\hline Number of trees (height $>1.3 \mathrm{~m}$ ) per hectare & 4950 & 3825 & 3975 & 3250 & 4125 \\
\hline Mean tree height $(\mathrm{m})$ & $4.72(0.09) \mathrm{a}$ & $4.94(0.10) \mathrm{a}$ & $5.17(0.18) \mathrm{a}$ & $5.06(0.20) \mathrm{a}$ & $5.22(0.11) \mathrm{a}$ \\
\hline Mean diameter at breast height $(\mathrm{cm})$ & 4.58 (2.09) a & $4.88(1.88) \mathrm{a}$ & $4.35(2.63) \mathrm{a}$ & $4.33(2.20) \mathrm{a}$ & $4.45(2.95) \mathrm{a}$ \\
\hline Leaf area index (LAI) & $2.57(0.55) \mathrm{a}$ & $2.54(0.33) \mathrm{a}$ & $2.20(0.9) \mathrm{a}$ & $2.27(0.31) \mathrm{a}$ & $2.20(0.62) \mathrm{a}$ \\
\hline $\mathrm{N}(\%)$ in soil organic layer & $1.01(0.19) \mathrm{a}$ & $0.83(0.22) \mathrm{a}$ & $1.09(0.30) \mathrm{a}$ & $0.63(0.37) \mathrm{a}$ & $1.14(0.31) \mathrm{a}$ \\
\hline $\mathrm{N}(\%)$ in mineral soil $0-5 \mathrm{~cm}$ & $0.08(0.02) \mathrm{a}$ & $0.11(0.02) \mathrm{a}$ & $0.11(0.04) \mathrm{a}$ & $0.08(0.03) \mathrm{a}$ & $0.12(0.09) \mathrm{a}$ \\
\hline $\mathrm{N}(\%)$ in mineral soil $5-15 \mathrm{~cm}$ & $0.07(0.01) \mathrm{a}$ & $0.06(0.03) \mathrm{a}$ & $0.06(0.00) \mathrm{a}$ & $0.06(0.00) \mathrm{a}$ & $0.05(0.01) \mathrm{a}$ \\
\hline $\mathrm{C}(\%)$ in soil organic layer & $33.00(7.10) \mathrm{a}$ & $30.07(10.85) \mathrm{a}$ & $33.08(8.07) \mathrm{a}$ & $22.88(15.53) b$ & $36.62(6.65) \mathrm{a}$ \\
\hline $\mathrm{C}(\%)$ in mineral soil $0-5 \mathrm{~cm}$ & $2.22(0.33) \mathrm{a}$ & $2.75(0.80) \mathrm{a}$ & $3.00(1.75) \mathrm{a}$ & $2.18(0.93) \mathrm{a}$ & $3.03(1.73) \mathrm{a}$ \\
\hline $\mathrm{C}(\%)$ in mineral soil $5-15 \mathrm{~cm}$ & $1.21(0.06) \mathrm{a}$ & $1.05(0.68) \mathrm{a}$ & $1.25(0.25) \mathrm{a}$ & $1.21(0.17) \mathrm{a}$ & $0.99(0.18) \mathrm{a}$ \\
\hline $\mathrm{C} / \mathrm{N}$ in soil organic layer & $32.56(3.23) \mathrm{a}$ & $35.50(5.00) \mathrm{a}$ & $30.56(1.90) \mathrm{a}$ & $34.08(6.42) \mathrm{a}$ & $32.91(5.42) \mathrm{a}$ \\
\hline $\mathrm{C} / \mathrm{N}$ in mineral soil $0-5 \mathrm{~cm}$ & $28(3.43) \mathrm{a}$ & $24.06(2.29) \mathrm{a}$ & $24.82(6.03) \mathrm{a}$ & $27.56(9.09) \mathrm{a}$ & $26.80(4.42) \mathrm{a}$ \\
\hline $\mathrm{C} / \mathrm{N}$ in mineral soil $5-15 \mathrm{~cm}$ & $18.40(4.6) \mathrm{a}$ & $18.09(2.34) \mathrm{a}$ & $19.59(3.20) \mathrm{a}$ & 20.59 (2.19) a & $18.97(0.35) \mathrm{a}$ \\
\hline $\mathrm{pH}$ & $4.49(0.32) \mathrm{a}$ & $4.54(0.24) \mathrm{a}$ & $4.48(0.44) \mathrm{a}$ & $4.44(0.17) \mathrm{a}$ & $4.64(0.34) \mathrm{a}$ \\
\hline Bulk density $\left(\mathrm{g} / \mathrm{cm}^{3}\right)$ & $0.53(0.08) \mathrm{a}$ & $0.56(0.09) \mathrm{a}$ & $0.51(0.11) \mathrm{a}$ & $0.52(0.09) \mathrm{a}$ & $0.51(0.12) \mathrm{a}$ \\
\hline Electric conductivity ( $\mu \mathrm{s} / \mathrm{cm})$ & $41.88(13.56) \mathrm{a}$ & $39.13(15.64) \mathrm{a}$ & $40.14(15.14) \mathrm{a}$ & $42.50(13.60) \mathrm{a}$ & $38.13(15.79) \mathrm{a}$ \\
\hline Silt $(\%)$ in mineral soil $0-5 \mathrm{~cm}$ & 18.43 & 12.94 & 15.80 & 16.75 & 13.62 \\
\hline Sand $(\%)$ in mineral soil $0-5 \mathrm{~cm}$ & 81.57 & 87.06 & 84.2 & 83.25 & 86.38 \\
\hline Silt (\%) in mineral soil $5-15 \mathrm{~cm}$ & 12.08 & 10.52 & 14.63 & 14.93 & 11.23 \\
\hline Sand $(\%)$ in mineral soil $5-15 \mathrm{~cm}$ & 87.92 & 89.48 & 85.37 & 85.07 & 88.77 \\
\hline
\end{tabular}

an elemental analyzer (VarioMax CN, Elementar Analysen Systeme GmbH, Hanau, Germany). PH were determined using a pH meter (PHM210, Radiometer Analytical, France) on a 1:2.5 (v:v) sample/water solution. Electric conductivity (EC) was measured by an electric meter (JENWAY 4010 Conductivity, TER Calibration Ltd., Wigan, UK). Soil particle size distribution was determined by a Coulter LS device (LS230, Coulter Corp., Miami, FL, America). The loss on ignition (LOI) of biochar was determined by combusting samples at $550{ }^{\circ} \mathrm{C}$ for $3 \mathrm{~h}$. The concentrations of $\mathrm{P}, \mathrm{K}, \mathrm{Ca}, \mathrm{Mg}, \mathrm{S}, \mathrm{Fe}, \mathrm{Al}, \mathrm{Na}, \mathrm{Cu}, \mathrm{Mn}, \mathrm{Ni}, \mathrm{Si}$, and $\mathrm{Zn}$ in the biochar were determined by an ICP atomic emission spectrophotometer (ARL 3580 OES, Fison Instruments, Valencia, USA). Characteristics of soil and biochar are presented in Tables 1 and 2 (Palviainen et al. 2018), respectively.

\subsubsection{Soil microbial biomass}

Nine soil samples from per plot were collected for microbial biomass $\mathrm{C}$ and $\mathrm{N}$ analysis in May, August, and September. Samples were taken from the humus layer using a stainless soil corer (diameter $10 \mathrm{~cm}$ ) close to those sampling points where the soil samples were taken for the soil analyses. The samples were put into $45-\mathrm{mL}$ plastic containers and kept in an ice box before storage at $-20^{\circ} \mathrm{C}$. Prior to analysis, soil samples were incubated at $4{ }^{\circ} \mathrm{C}$ for 7-9 days. The nine samples from each subplot were pooled into three samples after removing visible stones, coarse roots, and leaves and sieving through a 2-mm sieve. Soil microbial biomass $\mathrm{C}$ and $\mathrm{N}$ were measured by a slightly modified chloroform fumigation extraction method (Joergensen 1996). Three grams of fresh soil (diameter $<2 \mathrm{~mm}$ ) from each sample was weighed and placed into glass beakers, then fumigated with $50 \mathrm{~mL}$ ethanol-free chloroform $\left(\mathrm{CHCl}_{3}\right)$ in a vacuum desiccator. Another sample of $3 \mathrm{~g}$ was placed in plastic bottles in another desiccator as non-fumigated control samples. Both desiccators were kept at $25{ }^{\circ} \mathrm{C}$ in the dark for $24 \mathrm{~h}$. After fumigation, $0.5 \mathrm{M}$ potassium sulfate $\left(\mathrm{K}_{2} \mathrm{SO}_{4}\right)$ was used to extract the fumigated and non-fumigated samples (oven-dry basis soil: $\mathrm{K}_{2} \mathrm{SO}_{4}=$ 1:20). Then, the samples were shaken at 200 RPM for $1 \mathrm{~h}$ and filtered through Whatman no. 42 filter papers. The filtrate was then used to analyze the microbial $\mathrm{C}$ and $\mathrm{N}$ by a TOC- $\mathrm{V}_{\mathrm{CPH}}$ analyzer (Shimadzu Corp., Kyoto, Japan). The microbial biomass $\mathrm{C}$ and $\mathrm{N}\left(\mathrm{mg} \mathrm{g}^{-1}\right)$ were calculated as:

Microbial biomass $\mathrm{C} / \mathrm{N}$

$$
=\frac{\left(\frac{F \cdot(V 1 / 1000)}{M 1}-\frac{U F \cdot(V 2 / 1000)}{M 2}\right)}{K}
$$


Table 2 Comparison of three linear mixed models with the base model. $T$ is treatment, $M$ is month, $B$ is block, $C$ is the collar in plot, $R_{\text {May }}$ is soil $\mathrm{CO}_{2}$ efflux in May (prior to treatments) as covariate, Tem is soil temperature, $M o i$ is soil moisture, and $\ln (R)$ is natural logarithm of soil $\mathrm{CO}_{2} ; a$ denotes the coefficients of fixed effects and $\alpha$ denotes the coefficients for random factors; $\varepsilon$ is the error term. Equation 5 tests if biochar application increases the soil $\mathrm{CO}_{2}$ efflux while Eqs. 6-8 test if soil $\mathrm{CO}_{2}$ efflux differs at a given value of soil moisture and soil temperature. Comparison among models was done by the chi-squared test. $P$ value means the difference between each linear mixed model and the base model

\begin{tabular}{|c|c|c|c|c|c|}
\hline Model & AIC & $\mathrm{BIC}$ & LogLik & Chi-square & $P$ value \\
\hline Equation 5: $\ln (R)=a_{1}+a_{2} T+a_{3} M+a_{4} R_{\text {May }}+\alpha_{1} B+\alpha_{2} C+\varepsilon$ & 777.47 & 827.53 & -376.74 & NA & NA \\
\hline Equation 6: $\ln (R)=a_{1}+a_{2} T+a_{3} M+a_{4} R_{\text {May }}+a_{5}$ Moi $+\alpha_{1} B+\alpha_{2} C+\varepsilon$ & 774.22 & 845.14 & -370.11 & 0.00 & $>0.05$ \\
\hline Equation 7: $\ln (R)=a_{1}+a_{2} T+a_{3} M+a_{4} R_{\text {May }}+a_{5}$ Tem $+\alpha_{1} B+\alpha_{2} C+\varepsilon$ & 684.12 & 755.04 & -325.06 & 103.35 & $<0.05$ \\
\hline Equation 8: $\ln (R)=a_{1}+a_{2} T+a_{3} M+a_{4} R_{\text {May }}+a_{5}$ Tem $+a_{6}$ Moi $+\alpha_{1} B+\alpha_{2} C+\varepsilon$ & 647.72 & 739.50 & -301.86 & 136.50 & $<0.05$ \\
\hline
\end{tabular}

where $F\left(\mathrm{mg} \mathrm{L}^{-1}\right)$ is the total organic $\mathrm{C}$ or total $\mathrm{N}$ concentration of a fumigated sample, $V 1(\mathrm{~mL})$ is the volume of $\mathrm{K}_{2} \mathrm{SO}_{4}$ added to extract a fumigated sample, 1000 is the unit conversion factor (for converting $\mathrm{mL}$ into $\mathrm{L}), M 1(\mathrm{~g})$ is the dry mass of a fumigated sample, $U F\left(\mathrm{mg} \mathrm{L}^{-1}\right)$ is the total organic $\mathrm{C}$ or total $\mathrm{N}$ concentration of a non-fumigated sample, $V 2(\mathrm{~mL})$ is the volume of $\mathrm{K}_{2} \mathrm{SO}_{4}$ added to extract a non-fumigated sample, $M 2$ (g) is the dry mass of a non-fumigated sample, and $K$ is the soil-specific calibration factor set to 0.45 for $\mathrm{C}$ (Beck et al. 1997) or 0.54 for N (Brookes et al. 1985).

\subsubsection{Soil respiration}

The collars (diameter $22 \mathrm{~cm}$ ) for soil $\mathrm{CO}_{2}$ efflux measurements were inserted permanently at $0.02-\mathrm{m}$ depth in the mor layer above the rooting zone to avoid damaging the roots and were sealed with a thin layer of sand placed around both the inner and outer sides of the collars to prevent leakage during flux measurements. Ground vegetation inside the collars remained intact. Six collars were distributed randomly in each of the 20 plots for soil respiration measurements. Thus, there were 24 collars in each treatment and 120 collars in total.

Soil $\mathrm{CO}_{2}$ efflux was measured with a closed chamber system consisting of a darkened cylindrical polycarbonate chamber (diameter $20 \mathrm{~cm}$, height $30 \mathrm{~cm}$ ), a $\mathrm{CO}_{2}$ analyzer, a sensor for relative humidity and temperature, and a data logger (Pumpanen et al. 2015). The chamber was placed onto the collars only during the measurements, which lasted $4 \mathrm{~min}$. During the measurements, air inside the chamber was mixed continuously by a small fan. The $\mathrm{CO}_{2}$ concentration inside the chamber was recorded with a GMP343 diffusion-type $\mathrm{CO}_{2}$ probe (Vaisala Oyj, Vantaa, Finland) at 5-s intervals and corrected automatically for humidity, temperature, and pressure with a data recorder (MI70, Vaisala Oyj) using the readings from the temperature and humidity probe (HMP75, Vaisala Oyj) inside the chamber. Air pressure was measured daily at the nearby (4 $\mathrm{km}$ away) Station for Measuring Ecosystem-Atmosphere Relations (SMEAR II) (Schobesberger et al. 2016). The $\mathrm{CO}_{2}$ efflux was calculated as the slope of a linear regression of $\mathrm{CO}_{2}$ concentration in the chamber against time. Only measurements taken between $45 \mathrm{~s}$ and $3 \mathrm{~min}$ after the closure were included in the fitting.

Soil temperature at a $5-\mathrm{cm}$ depth was measured by a dualinput digital thermometer (Fluke-52-2, Fluke Corp.). Volumetric water content was measured by a ThetaProbetype moisture meter simultaneously near the collar $(\mathrm{HH} 2$, Delta-T Devices Ltd., Cambridge, UK). The measurements were performed between 9:00 and 11:00 am on clear days at approximately the end of each month starting in May 2015 (before biochar amendment) and finishing in September 2015.

An exponential regression model was used to describe the relationship between soil $\mathrm{CO}_{2}$ and soil temperature:

$\mathrm{y}=a \times \exp (k t)$

where $y$ is the soil respiration, $t$ is the soil temperature at $5-\mathrm{cm}$ depth, and $a$ and $k$ are the model coefficients. The temperature sensitivity, $Q_{10}$, was calculated from this model using the following equation (Liu et al. 2011; Luo et al. 2011; Song et al. 2013):

$Q_{10}=\exp (10 k)$

\subsection{Statistical analysis}

The effect of biochar application on soil temperature, soil moisture, $\mathrm{pH}, \mathrm{EC}, \mathrm{MBC}, \mathrm{MBN}, \mathrm{MBC} / \mathrm{N}$, and soil $\mathrm{CO}_{2}$ efflux were analyzed with linear mixed model followed by Fisher's least significant difference (LSD) test. Treatment and month were taken as fixed factors, and block and the collar were set as random factors. In soil $\mathrm{CO}_{2}$ analysis, the soil $\mathrm{CO}_{2}$ efflux in May of each collar was used as covariate, as this measurement preceded the biochar applications and collars were not moved during the experiments. This was done because soil $\mathrm{CO}_{2}$ efflux varies between sites and collars. These pre-treatment values as covariates have been used to adjust the soil $\mathrm{CO}_{2}$ effluxes for variation in soil properties within our experiment. The relationship between 
soil $\mathrm{CO}_{2}$ efflux and soil temperature and moisture among different treatments was tested by three different linear mixed models, and we compared them to the base model by the chi-squared test. The model comparison was performed with $\mathrm{R}$ version 3.5.3 using stats package ( $\mathrm{R}$ Core Team 2019). We used mixed models for the analysis of our results since they provide a more flexible approach for nested repeated measures designs as in our experiment. Our analysis follows the approach suggested by Cleophas and Zwinderman (2012) in chapter 55 as well as the approach by Kulmala et al. (2014).

Differences in soil temperature, soil moisture, $\mathrm{pH}, \mathrm{EC}$, $\mathrm{MBC}, \mathrm{MBN}$, and $\mathrm{MBC} / \mathrm{N}$ among treatments were estimated by a linear mixed model (Eq. 4):

$Y_{i}=a_{1+} a_{2} T+a_{3} M+\alpha_{1} B+\alpha_{2} C+\varepsilon_{i}$

where $Y_{i}$ is measured value of the observation $i$ of the respective environmental variable (soil temperature, moisture, $\mathrm{pH}$, $\mathrm{EC}, \mathrm{MBC}, \mathrm{MBN}$, and $\mathrm{MBC} / \mathrm{N}) . T$ is treatment, $M$ is month, $B$ is block, $C$ is the collar in plot, $a$ denotes the coefficients of fixed effects and $\alpha$ denotes the coefficients for random factors, and $\varepsilon$ is the error term. All statistical analyses were performed using IBM SPSS Statistics 23.0 (IBM Crop., Armonk, NY). Differences were considered statistically significant when $P$ value was $<0.05$.

The base model (Eq. 5) estimates differences of soil $\mathrm{CO}_{2}$ efflux among treatments without accounting for differences in the physical environment:

$\ln (R)=a_{1}+a_{2} T+a_{3} M+a_{4} R_{\text {May }}+\alpha_{1} B+\alpha_{2} C+\varepsilon$

where $\ln (R)$ is the natural logarithm of soil $\mathrm{CO}_{2}$ and $R_{\text {May }}$ is soil $\mathrm{CO}_{2}$ efflux in May (prior to treatments) as covariate.

The linear mixed models estimate differences of soil $\mathrm{CO}_{2}$ efflux among treatments at a given value of soil moisture (Eq. 6) or soil temperature (Eq. 7) or both (Eq. 8):

$$
\begin{aligned}
\ln (R)= & a_{1}+a_{2} T+a_{3} M+a_{4} R_{\text {May }}+a_{5} \text { Moi }+\alpha_{1} B \\
& +\alpha_{2} C+\varepsilon \\
\ln (R)= & a_{1}+a_{2} T+a_{3} M+a_{4} R_{\text {May }}+a_{5} \text { Tem }+\alpha_{1} B \\
& +\alpha_{2} C+\varepsilon \\
\ln (R)= & a_{1}+a_{2} T+a_{3} M+a_{4} R_{\text {May }}+a_{5} \text { Tem }+a_{6} \text { Moi } \\
& +\alpha_{1} B+\alpha_{2} C+\varepsilon
\end{aligned}
$$

where Tem is soil temperature and Moi is soil moisture. We emphasize that the hypotheses behind Eq. 5 and Eqs. 6-8 are different. Equation 5 tests if biochar application increases the soil $\mathrm{CO}_{2}$ efflux while Eqs. 6-8 test if soil $\mathrm{CO}_{2}$ efflux differs at a given value of soil moisture and soil temperature.

\section{Results}

\subsection{Physicochemical environment in different treatments}

\subsubsection{Soil temperature and moisture dynamics in different treatments}

The mean soil temperatures in biochar treatments T500M0.5, T500M1.0, and T650M1.0 were significantly higher $(P<0.05)$ compared with those in the control (Fig. 1a). The mean soil temperature was highest in T650M1.0 $\left(12.1^{\circ} \mathrm{C}\right)$ and lowest in the control $\left(11.4{ }^{\circ} \mathrm{C}\right)$ (Table 4$)$. The amount of BC650 affected soil temperature significantly. Soil temperature in all treatments increased from May to August (the warmest month) and then dropped in September but remained higher than in May (Fig. 3a).

Responses of soil moisture to biochar application were not consistent. The mean soil moisture increased significantly in T500M0.5 $(P<0.05)$ and decreased significantly in T500M1.0 $(P<0.05)$ compared with that in control (Fig. $1 b)$. The mean soil moisture was highest in T500M0.5 $\left(0.14 \mathrm{~m}^{3} \mathrm{~m}^{-3}\right)$ and lowest in T500M1.0 $\left(0.11 \mathrm{~m}^{3} \mathrm{~m}^{-3}\right)$ (Fig. 1b). Soil moisture with each treatment changed only slightly between May and July, then decreased sharply in August (the driest month) and increased again in September (Fig. 3b).

\subsubsection{Soil pH and EC dynamics in different treatments}

T500M1.0, T650M0.5, and T650M1.0 showed significant increases in soil $\mathrm{pH}(P<0.05)$. The highest mean $\mathrm{pH}$ was measured in T500M1.0 $(\mathrm{pH}=3.71)$ and the lowest in the control $(\mathrm{pH}=3.55)$. The $\mathrm{pH}$ in treatments with $1.0 \mathrm{~kg} \mathrm{~m}^{-2}$ biochar was always significantly higher than in those with $0.5 \mathrm{~kg} \mathrm{~m}^{-2}$ biochar $(P<0.05)$ (Fig. 1c, Table 4).

Electric conductivity (EC) was highest in T500M0.5 $\left(183.6 \mu \mathrm{s} \mathrm{cm}^{-1}\right)$ and lowest in control $\left(168.9 \mu \mathrm{s} \mathrm{cm}^{-1}\right)$. The average increase of EC was $12.2 \mu \mathrm{s} \mathrm{cm}^{-1}$ and $5.4 \mu \mathrm{s} \mathrm{cm}^{-1}$ in $0.5 \mathrm{~kg} \mathrm{~m}^{-2}$ and $1 \mathrm{~kg} \mathrm{~m}^{-2}$ biochar treatments, respectively (Fig. 1d, Table 4).

\subsection{Dynamics of $\mathbf{C}$ and $\mathbf{N}$ in microbial biomass in different treatments}

The difference in the amount of $\mathrm{C}$ and $\mathrm{N}$ in the microbial biomass among the treatments was not statistically significant $(P>0.05)$ (Fig. 2a, b). The $\mathrm{C} / \mathrm{N}$ ratios of microbial biomass were lower for biochar treatments (8.43) compared with those for the control (8.86); the difference was not statistically significant $(P>0.05)$ (Fig. 2c). The microbial biomass showed a clear seasonal pattern and increased over the growing season. The $\mathrm{C} / \mathrm{N}$ ratio decreased during the same time. Biochar did not have any effect on the seasonal dynamics, and there was no 


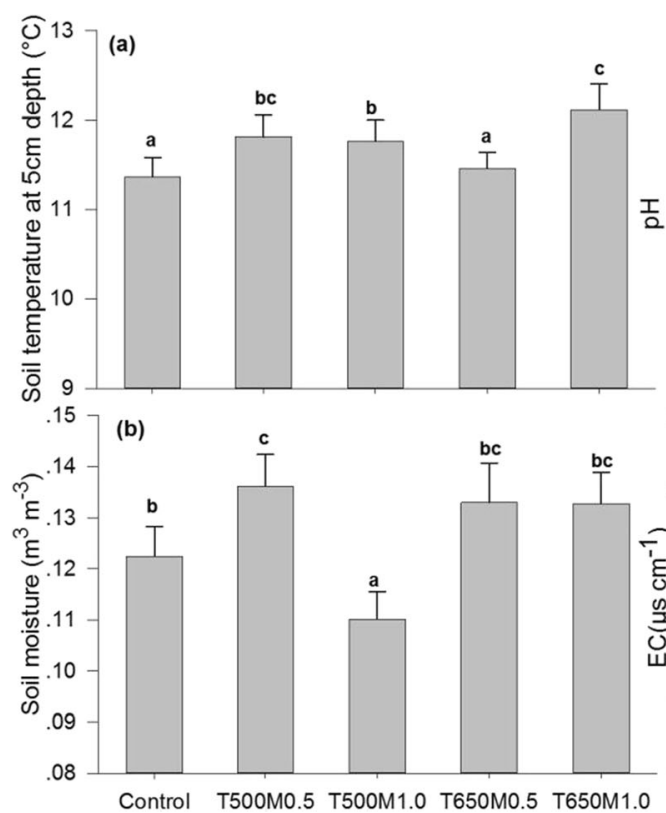

Fig. 1 Mean $( \pm \mathrm{SE})$ soil temperature at 5-cm depth (a) and mean soil moisture (b) from June to September and mean soil pH (c) and mean electric conductivity (d) of August and September in different treatments (6 sample points in each block, 4 blocks for each treatment). T500M1.0 denotes plots that were amended with biochar produced at $500{ }^{\circ} \mathrm{C}$ at a rate of $1.0 \mathrm{~kg} \mathrm{~m}^{2}$; T500M0.5 denotes plots that were amended with biochar produced at $500{ }^{\circ} \mathrm{C}$ at a rate of $0.5 \mathrm{~kg} \mathrm{~m}^{2}$; T650M1.0 denotes plots that

indication that biochar would change the dynamics of microbial biomass in our site $(P>0.05)$ (Fig. $3 \mathrm{~d}-\mathrm{f})$.

\subsection{Soil $\mathrm{CO}_{2}$ efflux dynamics in different treatments}

Mean soil $\mathrm{CO}_{2}$ fluxes increased by $10 \mu \mathrm{g} \mathrm{m}^{-2} \mathrm{~h}^{-1}$ (for T500M0.5), $70 \mu \mathrm{g} \mathrm{m}^{-2} \mathrm{~h}^{-1}$ (T650M0.5), $132 \mu \mathrm{g} \mathrm{m}^{-2} \mathrm{~h}^{-1}$ (T650M1.0), and $156 \mu \mathrm{g} \mathrm{m}^{-2} \mathrm{~h}^{-1}$ (T500M1.0), lowest in the control $\left(868 \mu \mathrm{g} \mathrm{m}^{-2} \mathrm{~h}^{-1}\right)$ and highest in T500M1.0 $\left(1024 \mu \mathrm{g} \mathrm{m}^{-2} \mathrm{~h}^{-1}\right)$. Soil $\mathrm{CO}_{2}$ fluxes increased $14.3 \%$ $(P<0.05)$ in $1.0 \mathrm{~kg} \mathrm{~m}^{-2}$ treatments and $4.6 \%(P>0.05)$ in $0.5 \mathrm{~kg} \mathrm{~m}^{-2}$ treatments. Pyrolysis temperature of biochar did not affect soil $\mathrm{CO}_{2}$ effluxes (Fig. 2d). Soil $\mathrm{CO}_{2}$ efflux increased over time from May to July, then decreased (Fig. 3c, Appendix Table 4).

\subsection{Comparison using linear mixed models}

When no environmental factors were included in Eq. 5, $1.0 \mathrm{~kg} \mathrm{~m}^{-2}$ biochar treatments had significantly higher $\mathrm{CO}_{2}$ effluxes than the control $(P<0.05)$. Table 2 shows that Eq. 6 (only taking soil moisture into account) performed only slightly $(P>0.05)$ better fit to the data compared with Eq. 5 . Inclusion of temperature (Eq. 7) led to an obviously $(P<0.05)$ improved performance (as well as indicated by a large drop in the AIC values). The combined model (Eq. 8) had the lowest AIC; the treatment effects were not significant

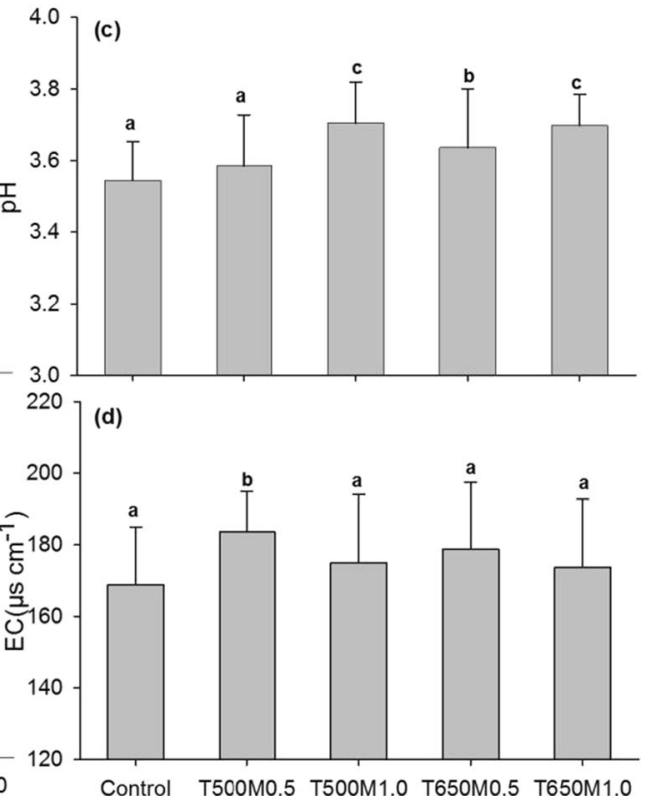

were amended with biochar produced at $650{ }^{\circ} \mathrm{C}$ at a rate of $1.0 \mathrm{~kg} \mathrm{~m}^{2}$; T650M0.5 denotes plots that were amended with biochar produced at $650{ }^{\circ} \mathrm{C}$ at a rate of $0.5 \mathrm{~kg} \mathrm{~m}^{2}$; and control denotes plots without biochar amendment. Each treatment had four replicates. Comparison among treatments was analyzed by linear mixed model with Fisher's least significant difference (LSD) test. Different letters indicate statistically significant differences $(P<0.05)$ between treatments

$(P>0.05)$ while effects of soil temperature and soil moisture were statistically significant $(P<0.05)$ (Table 3$)$ Detail results of Eq. 8 shows the relationships between soil $\mathrm{CO}_{2}$ fluxes and soil temperature and moisture among treatments in Appendix Table 5.

\subsection{The relationships between soil physical properties and soil $\mathrm{CO}_{2}$ efflux}

An exponential relationship was found between soil temperature at $5 \mathrm{~cm}$, soil moisture, and soil $\mathrm{CO}_{2}$ effluxes. The $R^{2}$ was 0.23 for soil $\mathrm{CO}_{2}$ efflux at high soil moisture $(0.078$ $\left.0.412 \mathrm{~m}^{3} \mathrm{~m}^{-3}\right)$ and 0.09 at low soil moisture $(0.008$ $0.076 \mathrm{~m}^{3} \mathrm{~m}^{-3}$ ). The $Q_{10}$ values for high and low moisture conditions were 2.59 and 1.48, respectively (Fig. 4).

\section{Discussion}

Few studies have investigated in situ the transient effects of biochar addition on soil $\mathrm{CO}_{2}$ efflux in boreal forests ( $\mathrm{Li}$ et al. 2018). Palviainen et al. (2018) investigated the long-term effect (after the second summer) of biochar application on carbon and nitrogen fluxes in the same site and found that soil $\mathrm{CO}_{2}$ effluxes showed no clear response to biochar addition. Only in June, the $1.0 \mathrm{~kg} \mathrm{~m}^{-2}$ biochar $\left(650^{\circ} \mathrm{C}\right)$ treatments had significantly higher $\mathrm{CO}_{2}$ effluxes compared with the control. 
Fig. 2 Mean ( \pm SE) soil microbial biomass $\mathrm{C}(\mathbf{a})$, mean soil microbial biomass $\mathrm{N}(\mathbf{b})$, mean soil microbial biomass $\mathrm{C}-\mathrm{N}$ ratio (c) of August and September, and mean soil $\mathrm{CO}_{2}$ fluxes (d) from June to September in different treatments from June to September (6 sample points in each block, 4 blocks for each treatment) (see Fig. 1 for details of treatments). Comparison among treatments was analyzed by linear mixed model with Fisher's least significant difference (LSD) test. Different letters indicate statistically significant differences $(P<0.05)$ between treatments
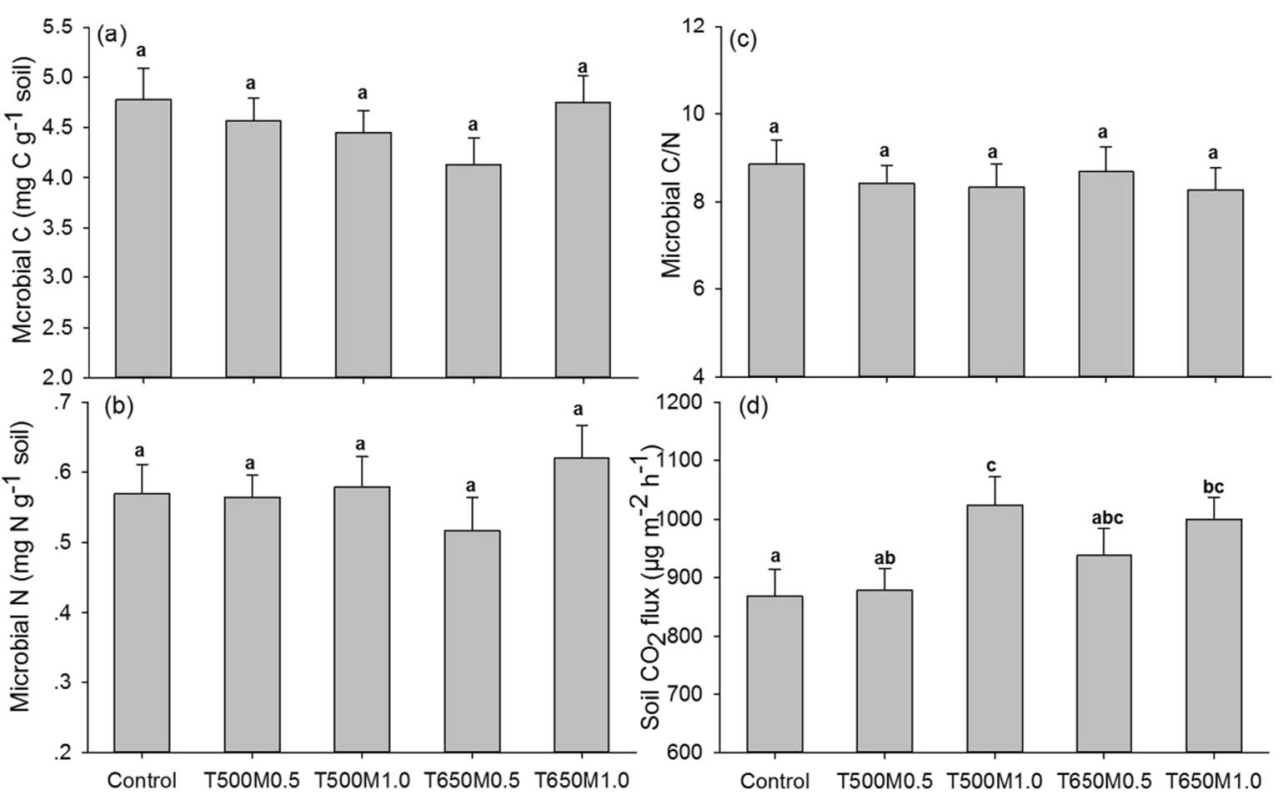

(d)

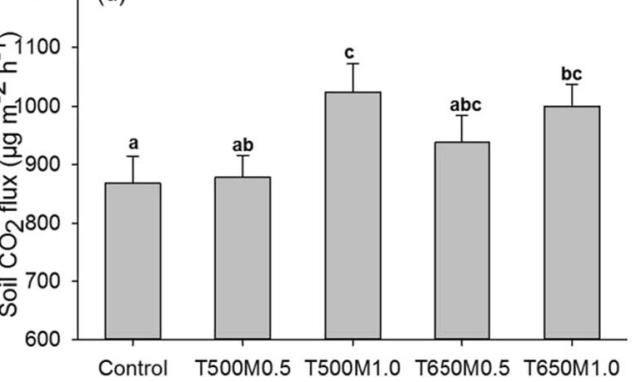

In our case, soil $\mathrm{CO}_{2}$ fluxes increased $14.3 \%(P<0.05)$ in $1.0 \mathrm{~kg} \mathrm{~m}^{-2}$ biochar treatments and $4.6 \%(P>0.05)$ in $0.5 \mathrm{~kg} \mathrm{~m}^{-2}$ biochar treatment relative to the control during the first summer after treatment. This change in soil $\mathrm{CO}_{2}$ efflux could stem from changes in the physical environment, or in the microbial biomass and activity. Our results suggest that changes in the physical environment dominate the response of soil $\mathrm{CO}_{2}$ efflux after biochar application. It seems that increases in temperature could be an important cause of the short-term changes in soil respiration. Although our data
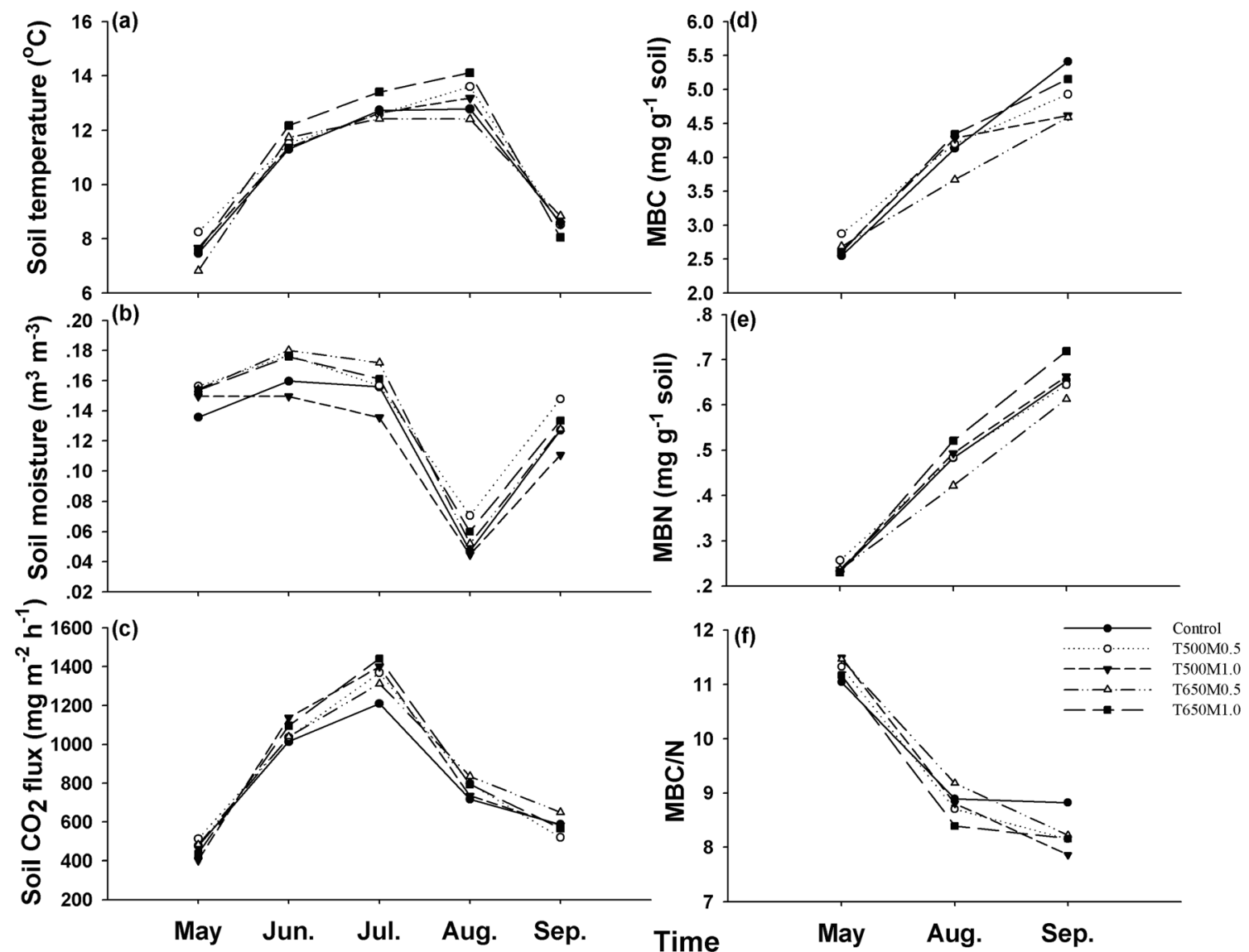

Fig. 3 Monthly dynamics of mean soil temperature at 5-cm depth (a), soil moisture (b), soil $\mathrm{CO}_{2}$ fluxes (c), soil microbial biomass $\mathrm{C}$ (d), soil microbial biomass $\mathrm{N}(\mathbf{e})$, and soil microbial biomass $\mathrm{C}-\mathrm{N}$ ratio (f) with different treatments (see Fig. 1 for details of treatments) 
Table 3 Significance of the fixed factors in each linear mixed model. $T$ is treatment, $M$ is month, $B$ is block, $C$ is the collar in plot, $R_{\text {May }}$ is soil $\mathrm{CO}_{2}$ efflux in May (prior to treatments) as covariate, Tem is soil temperature, $M o i$ is soil moisture, and $\ln (R)$ is natural logarithm of soil
$\mathrm{CO}_{2} ; a$ denotes the coefficients of fixed effects and $\alpha$ denotes the coefficients for random factors; $\varepsilon$ is the error term. Equation 5 tests if biochar application increases the soil $\mathrm{CO}_{2}$ efflux while Eqs. $6-8$ test if soil $\mathrm{CO}_{2}$ efflux differs at a given value of soil moisture and soil temperature

\begin{tabular}{|c|c|c|c|c|c|c|}
\hline Parameter & Treatment & $\begin{array}{l}\text { Soil } \mathrm{CO}_{2} \\
\text { in May }\end{array}$ & Moisture & $\begin{array}{l}\text { Treatment } \times \\
\text { moisture }\end{array}$ & Temperature & $\begin{array}{l}\text { Treatment } \times \\
\text { temperature }\end{array}$ \\
\hline Equation 5: $\ln (R)=a_{1}+a_{2} T+a_{3} M+a_{4} R_{\text {May }}+\alpha_{1} B+\alpha_{2} C+\varepsilon$ & 0.048 & 0.000 & - & - & - & - \\
\hline $\begin{array}{l}\text { Equation 6: } \\
\qquad \ln (R)=a_{1}+a_{2} T+a_{3} M+a_{4} R_{\mathrm{May}}+a_{5} \mathrm{Moi}+\alpha_{1} B+\alpha_{2} C+\varepsilon\end{array}$ & 0.791 & 0.000 & 0.001 & 0.689 & - & - \\
\hline $\begin{array}{l}\text { Equation 7: } \\
\quad \ln (R)=a_{1}+a_{2} T+a_{3} M+a_{4} R_{\mathrm{May}}+a_{5} \mathrm{Tem}+\alpha_{1} B+\alpha_{2} C+\varepsilon \\
\text { Equation 8: }\end{array}$ & 0.816 & 0.000 & - & - & 0.000 & 0.943 \\
\hline
\end{tabular}

suggests that soil $\mathrm{CO}_{2}$ efflux indeed increased after biochar application, the increases at given values of soil moisture and soil temperatures were non-significant (Table 3). This suggests that increases in temperature could be an important cause of soil $\mathrm{CO}_{2}$ changes. The inconsistent changes of soil moisture among treatments could affect the response of soil $\mathrm{CO}_{2}$ to temperature but did not change soil $\mathrm{CO}_{2}$ directly.

Microbial activity in high-latitude soils is strongly limited by temperature, so even small increases in soil temperature may increase soil $\mathrm{CO}_{2}$ efflux. One main reason for the observed increase in soil temperature in our study could be albedo decreased after biochar application (Vaccari et al. 2011; Genesio et al. 2012), during the whole experimental period,

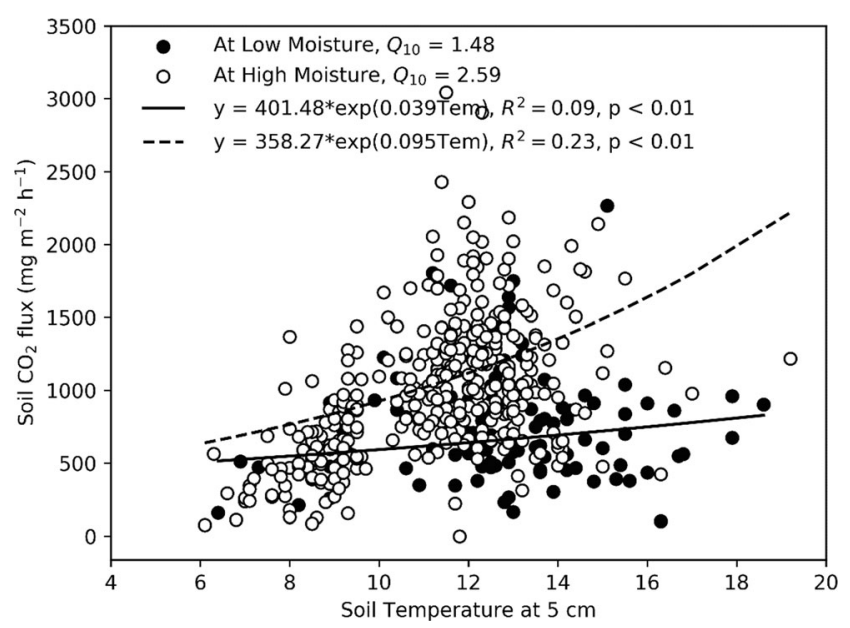

Fig. 4 Regressions of soil temperature and soil $\mathrm{CO}_{2}$ flux at different conditions in the study sites. Though the differences of soil $\mathrm{CO}_{2}$ among treatments disappear after correcting by soil moisture and temperature, soil $\mathrm{CO}_{2}$ flux responds to soil temperature more sensitively at high moisture condition relative to low moisture condition. $Q_{10}$ values for high and low moisture conditions are 2.59 and 1.48, respectively. Each point in the figure corresponds to one measurement of soil $\mathrm{CO}_{2}$, soil moisture, and soil temperature from one sample point (6 sample points in each plot, 5 treatment plots in each block, 4 blocks in our study from June to September). Hollow dots: high moisture $\left(0.078,0.412 \mathrm{~m}^{3} \mathrm{~m}^{-3}\right)$; solid dots: low moisture $\left(0.008,0.076 \mathrm{~m}^{3} \mathrm{~m}^{-3}\right)$ as biochar covered the vegetation on the ground. In contrast, the LAI of our site (Table 1) lack the height to keep the surface albedo unchanged after biochar application. In addition, the amount of biochar affected the increment of soil $\mathrm{CO}_{2}$, as $1.0 \mathrm{~kg} \mathrm{~m}^{-2}$ treatments had higher density of biochar cover on soil surface and lower albedo than $0.5 \mathrm{~kg} \mathrm{~m}^{-2}$ treatments, which led to higher soil temperature. The increases in soil temperature and $\mathrm{CO}_{2}$ efflux are probably transient as the biochar particles are incorporated into the soil and covered by vegetation over time (Palviainen et al. 2018). Similarly, Li et al. (2018) reported that initial soil $\mathrm{CO}_{2}$ increases in biochar experiments are more common than in long-term experiments (exceeding 90 days).

Notably, temperature differences due to biochar amendments (Fig. 1) fall partly within the error range of the sensor $( \pm 0.05 \%$ of reading $+0.3^{\circ} \mathrm{C}$ ). Other possible reasons for increased $\mathrm{CO}_{2}$ efflux after biochar addition are the decomposition of labile $\mathrm{C}$ of biochar, biochar-induced priming effects, or increased plant growth and root biomass (Lehmann et al. 2006; Cross and Sohi 2011). Studies from temperate forests have reported short-term weak positive priming effects or unchanged soil $\mathrm{CO}_{2}$ (Bruckman et al. 2015; Sackett et al. 2015). Gundale et al. (2016) and Palviainen et al. (2018) applied biochar to boreal forest soil and observed no significant effect on soil $\mathrm{CO}_{2}$ during two growing seasons. In general, positive priming effects emerge in soils with low C content (Zimmerman et al. 2011). Weak priming effects and moderate changes in $\mathrm{CO}_{2}$ effluxes in boreal forest soils after biochar addition may occur since boreal forest soils a have high $\mathrm{C}$ content (Deluca and Boisvenue 2012). In our case, biochar of 5 $10 \mathrm{~mm}$ grain size was spread on soil surface; the process of biochar decomposition and mixing with soil take time and do not show the priming effects that other authors had observed.

Biochar application had no significant effect on soil microbial biomass. Other studies also have found negligible changes in microbial biomass after biochar application. After biochar application in a boreal forest, Gundale et al. (2016) observed no large changes in soil respiration, in microbial biomass, or in the 
microbial community composition. Noyce et al. (2015) observed that biochar application in a temperate hardwood forest had no significant effect on microbial biomass after treatment. The microbial biomass of the humus layer changed over time in all treatments, probably caused by the seasonal dynamics of environmental factors (Wardle et al. 1998). Our results are consistent with the results of another study of northern forest ecosystems (Gundale et al. 2016), which indicated little or no changes in microbial biomass after biochar addition. The lack of response in microbial biomass supported our conclusion that the main drivers for the increase in soil respiration were changes in the physical environment of soil, especially temperature.

We observed that biochar increased soil $\mathrm{pH}$ due to the alkaline nature of biochar along with its high Ca content (Table 1), consistent with other studies (Ventura et al. 2013; Biederman and Harpole 2013; Masto et al. 2013; Zhao et al. 2015; Ahmed and Schoenau 2015). There was a positive relationship between the amount of biochar and soil $\mathrm{pH}$; this was also reported by Kim et al. (2016). Furthermore, electric conductivity increased after the biochar application, which is consistent with the findings of Ventura et al. (2013). The soluble ion concentrations in biochar likely increased the concentration of $\mathrm{Ca}^{2+}$ and $\mathrm{K}^{+}$ions in the soil solution and thereby contributed to the increase in soil EC (Kloss et al. 2014). However, our sampling framework did not allow testing for the effect of soil $\mathrm{pH}$ and $\mathrm{EC}$ on soil $\mathrm{CO}_{2}$ efflux.

Biochar added to the surface or mixed into the mineral soil can help increase water retention, reduce leaching, or improve bulk density in the soil (Ippolito et al. 2012). Unlike agricultural soils, where biochar can be added and tilled into the soil profile, application of biochar on forest sites is more challenging as trees, stumps, and downed wood hinder movement across a harvest unit (Page-Dumroese et al. 2016). In our study, to avoid soil disturbance and damage to roots, biochar was added to the growing forest and was spread on the soil surface instead of mixing into soil. Little biochar was lost from the area due to wind as the biochar was not powder but particles with 5-10 $\mathrm{mm}$ size. The transportation of biochar away with the surface water flow is was unlikely because the terrain is flat, the soil is well-drained coarse sand, and there were no heavy rains during the experiment period. The mossdominated vegetation did not suffer from biochar addition and remained stable (Palviainen et al. 2018) despite being covered by the biochar during the first growing season.

Previous studies have reported that soil $\mathrm{CO}_{2}$ efflux increases exponentially with soil temperature (Sheng et al. 2010; Karhu et al. 2011; Liu et al. 2011; Ventura et al. 2013; Song et al. 2013; Pumpanen et al. 2015). This relationship was also found in our study. Fang et al. (2015) proposed that biochar would protect SOM from decomposition by absorbing SOM on its surface leading to lower temperature sensitivity of soil respiration. However, the temperature sensitivity of soil respiration did not change significantly after biochar application. Since our soils were poor in clay minerals that might otherwise protect the biochar from decomposition, we would have expected a marked effect of biochar on the temperature sensitivity of soil respiration. Our data suggests, furthermore, that there are interactions between soil temperature, soil moisture, and soil respiration. Soil $\mathrm{CO}_{2}$ efflux was more responsive to temperature at high soil moisture contents (Fig. 4). This also explains why $\mathrm{CO}_{2}$ fluxes decreased sharply in dry August even though the soil temperature was high. The $Q_{10}$ values at high moisture contents were similar to those measured by Pumpanen et al. (2003) at a nearby similar forest site. Altogether, the $Q_{10}$ values measured in the present study were within the range of other studies from boreal forest soils, ranging from 0.98 (Gulledge and Schimel 2000) to 4.75 (Morén and Lindroth 2000). Our data does not suggest that these dependences on humidity and soil temperature would have changed due to the biochar application.

\section{Conclusions}

Our study on the short-term effects of biochar addition on soil $\mathrm{CO}_{2}$ efflux, microbial biomass, and soil properties in a boreal Scots pine forest indicated that the initial soil $\mathrm{CO}_{2}$ efflux responses were dominated by physical effects of biochar on soil temperature. The results showed that the amount of biochar affected soil $\mathrm{CO}_{2}$ efflux significantly, but pyrolysis temperature of biochar had no effect. Biochar amendment was found to increase soil $\mathrm{pH}$ but soil microbial biomass remained unchanged. The increases in soil temperature and $\mathrm{CO}_{2}$ efflux are probably transient as the biochar particles are incorporated in the soil and covered by vegetation over time. More studies are needed to get the optimum biochar amount for carbon sequestration in boreal forest.

Acknowledgments Open access funding provided by University of Eastern Finland (UEF) including Kuopio University Hospital. We thank the staff of the Hyytiälä Forestry Field Station for supporting us in the field work.

Funding information This study was funded by The Foundation for Research of Natural Resources in Finland (Suomen Luonnonvarain tutkimussäätiö) and the Academy of Finland research project ARCTICFIRE (286685), supported by grants from the Top Key Discipline of Forestry in Zhejiang A\&F University and Natural Science Foundation of China (31370641) and the FCoE of Atmospheric Sciences (Center of Excellence (1118615).

Data availability The datasets generated during and/or analyzed during the current study are available in the Zenodo repository, https://doi.org/ 10.5281/zenodo.3800097.

\section{Compliance with ethical standards}

Conflict of interest The authors declare that they have no conflict of interest.

\section{פ9 Springer INRAC}




\section{Appendix}

Table 4 The result of the linear mixed model analysis for the effects of treatment on soil temperature, soil moisture, $\mathrm{pH}$, electric conductivity, soil $\mathrm{CO}_{2}$ fluxes and pairwise comparisons between control and each treatment

\begin{tabular}{|c|c|c|c|c|c|}
\hline Estimates & Mean & Std. Error & $\mathrm{df}$ & Pairwise Comparisons & Significant $p$-values \\
\hline \multicolumn{6}{|c|}{ Soil temperature $\left({ }^{\circ} \mathrm{C}\right)$} \\
\hline Control & 11.365 & 0.273 & 4.313 & & \\
\hline T500M0.5 & 11.810 & 0.273 & 4.313 & Control VS T500M0.5 & 0.012 \\
\hline T500M1.0 & 11.763 & 0.273 & 4.313 & Control VS T500M1.0 & 0.024 \\
\hline T650M0.5 & 11.459 & 0.273 & 4.313 & Control VS T650M0.5 & 0.590 \\
\hline T650M1.0 & 12.114 & 0.273 & 4.313 & Control VS T650M1.0 & 0.000 \\
\hline \multicolumn{6}{|c|}{ Soil moisture $\left(\mathrm{m}^{2} \mathrm{~m}^{-2}\right)$} \\
\hline Control & 0.122 & 0.004 & 472 & & \\
\hline T500M0.5 & 0.136 & 0.004 & 472 & Control VS T500M0.5 & 0.029 \\
\hline T500M1.0 & 0.110 & 0.004 & 472 & Control VS T500M1.0 & 0.050 \\
\hline T650M0.5 & 0.133 & 0.004 & 472 & Control VS T650M0.5 & 0.094 \\
\hline T650M1.0 & 0.133 & 0.004 & 472 & Control VS T650M1.0 & 0.103 \\
\hline \multicolumn{6}{|l|}{$p H$} \\
\hline Control & 3.545 & 0.052 & 6.678 & & \\
\hline T500M0.5 & 3.586 & 0.052 & 6.678 & Control VS T500M0.5 & 0.274 \\
\hline T500M1.0 & 3.705 & 0.052 & 6.678 & Control VS T500M1.0 & 0.000 \\
\hline $\mathrm{T} 650 \mathrm{M} 0.5$ & 3.633 & 0.052 & 6.678 & Control VS T650M0.5 & 0.020 \\
\hline T650M1.0 & 3.698 & 0.052 & 6.678 & Control VS T650M1.0 & 0.000 \\
\hline \multicolumn{6}{|l|}{$E C\left(\mu s \mathrm{~cm}^{-1}\right)$} \\
\hline Control & 168.917 & 4.436 & 110.000 & & \\
\hline T500M0.5 & 183.583 & 4.436 & 110.000 & Control VS T500M0.5 & 0.021 \\
\hline T500M1.0 & 175.000 & 4.436 & 110.000 & Control VS T500M1.0 & 0.334 \\
\hline $\mathrm{T} 650 \mathrm{M} 0.5$ & 178.667 & 4.436 & 110.000 & Control VS T650M0.5 & 0.123 \\
\hline T650M1.0 & 173.667 & 4.436 & 110.000 & Control VS T650M1.0 & 0.451 \\
\hline \multicolumn{6}{|c|}{ Soil $\mathrm{CO}_{2}$ flux $\left(\mu \mathrm{g} \mathrm{m}^{-2} h^{-1}\right)$} \\
\hline Control & 868 & 46.710 & 110.774 & & \\
\hline T500M0.5 & 878 & 47.212 & 110.774 & Control VS T500M0.5 & 0.877 \\
\hline T500M1.0 & 1024 & 47.524 & 111.599 & Control VS T500M1.0 & 0.022 \\
\hline T650M0.5 & 938 & 46.756 & 110.774 & Control VS T650M0.5 & 0.288 \\
\hline T650M1.0 & 1000 & 46.800 & 110.774 & Control VS T650M1.0 & 0.048 \\
\hline
\end{tabular}


Table 5 Estimates of fixed factors in Eq. 8 explaining the relationships between soil $\mathrm{CO}_{2}$ fluxes and soil temperature and moisture when the treatment factor was considered

\begin{tabular}{|c|c|c|c|c|c|}
\hline \multirow[t]{2}{*}{ Parameter $^{\mathrm{a}}$} & \multirow[t]{2}{*}{ Estimate } & \multirow[t]{2}{*}{ Std. Error } & \multirow[t]{2}{*}{ Sig. } & \multicolumn{2}{|c|}{ 95\% Confidence Interval } \\
\hline & & & & Lower Bound & Upper Bound \\
\hline Intercept $\left(\mu \mathrm{g} \mathrm{m}^{-2} h^{-1}\right)$ & 4.439 & 0.564 & 0.000 & 3.333 & 5.545 \\
\hline [Treatment=T500M0.5] & -0.242 & 0.461 & 0.599 & -1.148 & 0.663 \\
\hline [Treatment=T500M1.0] & 0.224 & 0.447 & 0.617 & -0.655 & 1.103 \\
\hline [Treatment=T650M0.5] & 0.091 & 0.404 & 0.822 & -0.704 & 0.886 \\
\hline [Treatment=T650M1.0] & -0.190 & 0.443 & 0.669 & -1.061 & 0.682 \\
\hline [Treatment=Control] & $0^{\mathrm{b}}$ & 0.000 & & & \\
\hline Moisture $\left(m^{2} m^{-2}\right)$ & 2.625 & 0.922 & 0.005 & 0.813 & 4.437 \\
\hline$[$ Treatment $=\mathrm{T} 500 \mathrm{M} 0.5] *$ Moisture & -0.567 & 1.283 & 0.659 & -3.088 & 1.954 \\
\hline$[$ Treatment $=\mathrm{T} 500 \mathrm{M} 1.0] *$ Moisture & 0.334 & 1.395 & 0.811 & -2.407 & 3.075 \\
\hline$[$ Treatment $=\mathrm{T} 650 \mathrm{M} 0.5] *$ Moisture & -0.850 & 1.030 & 0.409 & -2.874 & 1.173 \\
\hline$[$ Treatment $=\mathrm{T} 650 \mathrm{M} 1.0] *$ Moisture & 1.580 & 1.347 & 0.242 & -1.068 & 4.227 \\
\hline$[$ Treatment $=$ Control $] *$ Moisture & $0^{\mathrm{b}}$ & 0.000 & & & \\
\hline Soil temperature $\left({ }^{\circ} \mathrm{C}\right)$ & 0.117 & 0.025 & 0.000 & 0.068 & 0.167 \\
\hline$[$ Treatment $=\mathrm{T} 500 \mathrm{M} 0.5] *$ Temperature & 0.017 & 0.034 & 0.609 & -0.049 & 0.084 \\
\hline$[$ Treatment $=\mathrm{T} 500 \mathrm{M} 1.0] *$ Temperature & -0.013 & 0.033 & 0.702 & -0.078 & 0.052 \\
\hline$[$ Treatment $=\mathrm{T} 650 \mathrm{M} 0.5] *$ Temperature & 0.002 & 0.031 & 0.961 & -0.060 & 0.063 \\
\hline$[$ Treatment $=\mathrm{T} 650 \mathrm{M} 1.0] *$ Temperature & 0.002 & 0.032 & 0.941 & -0.061 & 0.066 \\
\hline$[$ Treatment $=$ Control $] *$ Temperature & $0^{\mathrm{b}}$ & 0.000 & & & \\
\hline \multicolumn{6}{|l|}{ Covariance Parameters } \\
\hline May & 0.001 & 0.000 & 0.000 & 0.0009 & 0.0015 \\
\hline Residual & 0.208 & 0.014 & 0.000 & 0.182 & 0.238 \\
\hline Intercept $[$ subject = Area $]$ & 0.196 & 0.000 & & & \\
\hline Intercept $[$ subject $=$ Area $*$ Collar $]$ & 0.0098 & 0.006 & 0.128 & 0.003 & 0.035 \\
\hline
\end{tabular}

${ }^{a}$ Dependent Variable: Ln(flux)

${ }^{\mathrm{b}}$ This parameter is set to zero because it is redundant

Open Access This article is licensed under a Creative Commons Attribution 4.0 International License, which permits use, sharing, adaptation, distribution and reproduction in any medium or format, as long as you give appropriate credit to the original author(s) and the source, provide a link to the Creative Commons licence, and indicate if changes were made. The images or other third party material in this article are included in the article's Creative Commons licence, unless indicated otherwise in a credit line to the material. If material is not included in the article's Creative Commons licence and your intended use is not permitted by statutory regulation or exceeds the permitted use, you will need to obtain permission directly from the copyright holder. To view a copy of this licence, visit http://creativecommons.org/licenses/by/4.0/.

\section{References}

Ahmed HP, Schoenau JJ (2015) Effects of biochar on yield, nutrient recovery, and soil properties in a canola (Brassica napus L)-wheat (Triticum aestivum $\mathrm{L}$ ) rotation grown under controlled environmental conditions. BioEnergy Res 8:1183-1196. https://doi.org/10. 1007/s12155-014-9574-x
Ameloot N, Graber ER, Verheijen FGA, De Neve S (2013) Interactions between biochar stability and soil organisms: review and research needs: biochar stability and soil organisms. Eur J Soil Sci 64:379390. https://doi.org/10.1111/ejss.12064

Bamminger C, Poll C, Sixt C, Högy P, Wüst D, Kandeler E, Marhan S (2016) Short-term response of soil microorganisms to biochar addition in a temperate agroecosystem under soil warming. Agric Ecosyst Environ 233:308-317. https://doi.org/10.1016/j.agee.2016. 09.016

Beck T, Joergensen RG, Kandeler E, Makeschin F, Nuss E, Oberholzer HR, Scheu S (1997) An inter-laboratory comparison of ten different ways of measuring soil microbial biomass C. Soil Biol Biochem 29: 1023-1032. https://doi.org/10.1016/S0038-0717(97)00030-8

Biederman LA, Harpole WS (2013) Biochar and its effects on plant productivity and nutrient cycling: a meta-analysis. GCB Bioenergy 5:202-214. https://doi.org/10.1111/gcbb.12037

Brookes PC, Landman A, Pruden G, Jenkinson DS (1985) Chloroform fumigation and the release of soil nitrogen: a rapid direct extraction method to measure microbial biomass nitrogen in soil. Soil Biol Biochem 17:837-842. https://doi.org/10.1016/0038-0717(85) 90144-0

Bruckman VJ, Terada T, Uzun BB, Apaydın-Varol E, Liu J (2015) Biochar for climate change mitigation: tracing the in-situ priming 
effect on a forest site. Energy Procedia 76:381-387. https://doi.org/ 10.1016/j.egypro.2015.07.845

Bruun EW, Hauggaard-Nielsen H, Ibrahim N, Egsgaard H, Ambus P, Jensen PA, Dam-Johansen K (2011) Influence of fast pyrolysis temperature on biochar labile fraction and short-term carbon loss in a loamy soil. Biomass Bioenergy 35:1182-1189. https://doi.org/10. 1016/j.biombioe.2010.12.008

Cajander A (1949) Forest types and their significance. Acta For Fenn 56. https://doi.org/10.14214/aff.7396

Cleophas TJ, Zwinderman AH (2012) Statistics applied to clinical studies, 5 th edn. Springer, Dordrecht

Cross A, Sohi SP (2011) The priming potential of biochar products in relation to labile carbon contents and soil organic matter status. Soil Biol Biochem 43:2127-2134. https://doi.org/10.1016/j.soilbio. 2011.06.016

Deluca TH, Boisvenue C (2012) Boreal forest soil carbon: distribution, function and modelling. For Int J For Res 85:161-184. https://doi. org/10.1093/forestry/cps003

Fang Y, Singh B, Singh BP (2015) Effect of temperature on biochar priming effects and its stability in soils. Soil Biol Biochem 80: 136-145. https://doi.org/10.1016/j.soilbio.2014.10.006

FAO, IUSS. Working Group WRB (2015) World reference base for soil resources 2014, update 2015. International soil classification system for naming soils and creating legends for soil maps. World Soil Resources Reports 106, Rome

Genesio L, Miglietta F, Lugato E, Baronti S, Pieri M, Vaccari FP (2012) Surface albedo following biochar application in durum wheat. Environ Res Lett 7:014025. https://doi.org/10.1088/1748-9326/7/ $1 / 014025$

Glaser B, Haumaier L, Guggenberger G, Zech W (2001) The "Terra Preta" phenomenon: a model for sustainable agriculture in the humid tropics. Naturwissenschaften 88:37-41. https://doi.org/10. $1007 / \mathrm{s} 001140000193$

Gulledge J, Schimel JP (2000) Controls on soil carbon dioxide and methane fluxes in a variety of taiga forest stands in Interior Alaska. Ecosystems 3:269-282. https://doi.org/10.1007/s100210000025

Gundale MJ, Nilsson M-C, Pluchon N, Wardle DA (2016) The effect of biochar management on soil and plant community properties in a boreal forest. GCB Bioenergy 8:777-789. https://doi.org/10.1111/ gcbb. 12274

Hawthorne I, Johnson MS, Jassal RS, Black TA, Grant NJ, Smukler SM (2017) Application of biochar and nitrogen influences fluxes of CO2, CH4 and N2O in a forest soil. J Environ Manag 192:203214. https://doi.org/10.1016/j.jenvman.2016.12.066

He Y, Zhou X, Jiang L, Li M, du Z, Zhou G, Shao J, Wang X, Xu Z, Hosseini Bai S, Wallace H, Xu C (2017) Effects of biochar application on soil greenhouse gas fluxes: a meta-analysis. GCB Bioenergy 9:743-755. https://doi.org/10.1111/gcbb.12376

He X, Yin H, Sun X, Han L, Huang G (2018) Effect of different particlesize biochar on methane emissions during pig manure/wheat straw aerobic composting: insights into pore characterization and microbial mechanisms. Bioresour Technol 268:633-637. https://doi.org/ 10.1016/j.biortech.2018.08.047

Ippolito JA, Laird DA, Busscher WJ (2012) Environmental benefits of biochar. J Environ Qual 41:967-972. https://doi.org/10.2134/ jeq2012.0151

Joergensen RG (1996) The fumigation-extraction method to estimate soil microbial biomass: calibration of the $\mathrm{kEC}$ value. Soil Biology and Biochemistry 28(1):25-31

Johnson MS, Webster C, Jassal RS, Hawthorne I, Black TA (2017) Biochar influences on soil $\mathrm{CO} 2$ and $\mathrm{CH} 4$ fluxes in response to wetting and drying cycles for a forest soil. Sci Rep 7:6780. https:// doi.org/10.1038/s41598-017-07224-6

Jones DL, Rousk J, Edwards-Jones G, DeLuca TH, Murphy DV (2012) Biochar-mediated changes in soil quality and plant growth in a three year field trial. Soil Biol Biochem 45:113-124. https://doi.org/10. 1016/j.soilbio.2011.10.012

Karhu K, Mattila T, Bergström I, Regina K (2011) Biochar addition to agricultural soil increased $\mathrm{CH} 4$ uptake and water holding capacity results from a short-term pilot field study. Agric Ecosyst Environ 140:309-313. https://doi.org/10.1016/j.agee.2010.12.005

Kim H-S, Kim K-R, Yang JE, Ok YS, Owens G, Nehls T, Wessolek G, Kim KH (2016) Effect of biochar on reclaimed tidal land soil properties and maize (Zea mays L.) response. Chemosphere 142:153159. https://doi.org/10.1016/j.chemosphere.2015.06.041

Kloss S, Zehetner F, Wimmer B, Buecker J, Rempt F, Soja G (2014) Biochar application to temperate soils: effects on soil fertility and crop growth under greenhouse conditions. J Plant Nutr Soil Sci 177: 3-15. https://doi.org/10.1002/jpln.201200282

Kolb SE, Fermanich KJ, Dornbush ME (2009) Effect of charcoal quantity on microbial biomass and activity in temperate soils. Soil Sci Soc Am J 73:1173-1181. https://doi.org/10.2136/sssaj2008.0232

Kulmala L, Aaltonen H, Berninger F, Kieloaho AJ, Levula J, Bäck J, Hari P, Kolari P, Korhonen JFJ, Kulmala M, Nikinmaa E, Pihlatie M, Vesala T, Pumpanen J (2014) Changes in biogeochemistry and carbon fluxes in a boreal forest after the clear-cutting and partial burning of slash. Agric For Meteorol 188:33-44. https://doi.org/10.1016/ j.agrformet.2013.12.003

Kumar K, Gupta SC, Baidoo SK, Chander Y, Rosen CJ (2005) Antibiotic uptake by plants from soil fertilized with animal manure. J Environ Qual 34:2082-2085. https://doi.org/10.2134/jeq2005.0026

Lehmann J, Gaunt J, Rondon M (2006) Bio-char sequestration in terrestrial ecosystems - a review. Mitig Adapt Strateg Glob Change 11: 403-427. https://doi.org/10.1007/s11027-005-9006-5

Li Y, Hu S, Chen J, Müller K, Li Y, Fu W, Lin Z, Wang H (2018) Effects of biochar application in forest ecosystems on soil properties and greenhouse gas emissions: a review. J Soils Sediments 18:546-563. https://doi.org/10.1007/s11368-017-1906-y

Liu J, Jiang P, Wang H, Zhou G, Wu J, Yang F, Qian X (2011) Seasonal soil $\mathrm{CO} 2$ efflux dynamics after land use change from a natural forest to Moso bamboo plantations in subtropical China. For Ecol Manag 262:1131-1137. https://doi.org/10.1016/j.foreco.2011.06.015

Lu K, Yang X, Shen J, Robinson B, Huang H, Liu D, Bolan N, Pei J, Wang H (2014) Effect of bamboo and rice straw biochars on the bioavailability of $\mathrm{Cd}, \mathrm{Cu}, \mathrm{Pb}$ and $\mathrm{Zn}$ to Sedum plumbizincicola. Agric Ecosyst Environ 191:124-132. https://doi.org/10.1016/j. agee.2014.04.010

Luo Y, Durenkamp M, De Nobili M et al (2011) Short term soil priming effects and the mineralisation of biochar following its incorporation to soils of different $\mathrm{pH}$. Soil Biol Biochem 43:2304-2314. https:// doi.org/10.1016/j.soilbio.2011.07.020

Luo Y, Durenkamp M, De Nobili M et al (2013) Microbial biomass growth, following incorporation of biochars produced at $350^{\circ} \mathrm{C}$ or $700{ }^{\circ} \mathrm{C}$, in a silty-clay loam soil of high and low $\mathrm{pH}$. Soil Biol Biochem 57:513-523. https://doi.org/10.1016/j.soilbio.2012.10.033

Maestrini B, Nannipieri P, Abiven S (2015) A meta-analysis on pyrogenic organic matter induced priming effect. GCB Bioenergy 7:577590. https://doi.org/10.1111/gcbb.12194

Masto RE, Kumar S, Rout TK, Sarkar P, George J, Ram LC (2013) Biochar from water hyacinth (Eichornia crassipes) and its impact on soil biological activity. Catena 111:64-71

Mitchell PJ, Simpson AJ, Soong R, Simpson MJ (2015) Shifts in microbial community and water-extractable organic matter composition with biochar amendment in a temperate forest soil. Soil Biol Biochem 81:244-254. https://doi.org/10.1016/j.soilbio.2014.11.017

Morén A-S, Lindroth A (2000) CO2 exchange at the floor of a boreal forest. Agric For Meteorol 101:1-14. https://doi.org/10.1016/ S0168-1923(99)00160-4

Noyce GL, Basiliko N, Fulthorpe R, Sackett TE, Thomas SC (2015) Soil microbial responses over 2 years following biochar addition to a 
north temperate forest. Biol Fertil Soils 51:649-659. https://doi.org/ $10.1007 / \mathrm{s} 00374-015-1010-7$

Ouyang L, Yu L, Zhang R (2014) Effects of amendment of different biochars on soil carbon mineralisation and sequestration. Soil Res 52:46. https://doi.org/10.1071/SR13186

Page-Dumroese DS, Coleman MD, Thomas SC (2016) Opportunities and uses of biochar on forest sites in North America. In: Bruckman VJ, Apaydin Varol E, Uzun BB, Liu J (eds) Biochar. Cambridge University Press, Cambridge, pp 315-335

Palviainen M, Berninger F, Bruckman VJ, Köster K, de Assumpção CRM, Aaltonen H, Makita N, Mishra A, Kulmala L, Adamczyk B, Zhou X, Heinonsalo J, Köster E, Pumpanen J (2018) Effects of biochar on carbon and nitrogen fluxes in boreal forest soil. Plant Soil 425:71-85. https://doi.org/10.1007/s11104-018-3568-y

Peng Y, Thomas SC (2010) Influence of non-nitrogenous soil amendments on soil $\mathrm{CO} 2$ efflux and fine root production in an $\mathrm{N}$-saturated northern hardwood forest. Ecosystems 13:1145-1156. https://doi. org/10.1007/s10021-010-9379-5

Pirinen P, Simola H, Aalto J et al (2012) Tilastoja Suomen ilmastosta 1981-2010 (Climatological statistics of Finland 1981-2010). Finn Meteorol Inst Rep 2012

Prayogo C, Jones JE, Baeyens J, Bending GD (2014) Impact of biochar on mineralisation of $\mathrm{C}$ and $\mathrm{N}$ from soil and willow litter and its relationship with microbial community biomass and structure. Biol Fertil Soils 50:695-702. https://doi.org/10.1007/s00374-013-08845

Pumpanen J, Ilvesniemi H, Perämäki M, Hari P (2003) Seasonal patterns of soil $\mathrm{CO} 2$ efflux and soil air $\mathrm{CO} 2$ concentration in a Scots pine forest: comparison of two chamber techniques. Glob Change Biol 9: 371-382. https://doi.org/10.1046/j.1365-2486.2003.00588.x

Pumpanen J, Kulmala L, Lindén A et al (2015) Seasonal dynamics of autotrophic respiration in boreal forest soil estimated by continuous chamber measurements. 20:14

R Core Team (2019) R: a language and environment for statistical computing. R Foundation for Statistical Computing, Vienna

Robertson SJ, Rutherford PM, López-Gutiérrez JC, Massicotte HB (2012) Biochar enhances seedling growth and alters root symbioses and properties of sub-boreal forest soils. Can J Soil Sci 92:329-340. https://doi.org/10.4141/cjss2011-066

Sackett TE, Basiliko N, Noyce GL, Winsborough C, Schurman J, Ikeda C, Thomas SC (2015) Soil and greenhouse gas responses to biochar additions in a temperate hardwood forest. GCB Bioenergy 7:10621074. https://doi.org/10.1111/gcbb.12211

Schimmelpfennig S, Glaser B (2012) One step forward toward characterization: some important material properties to distinguish biochars. J Environ Qual 41:1001-1013. https://doi.org/10.2134/jeq2011.0146

Schobesberger S, Lopez-Hilfiker FD, Taipale D, Millet DB, D'Ambro EL, Rantala P, Mammarella I, Zhou P, Wolfe GM, Lee BH, Boy M, Thornton JA (2016) High upward fluxes of formic acid from a boreal forest canopy: high $\mathrm{HCOOH}$ fluxes from a boreal forest. Geophys Res Lett 43:9342-9351. https://doi.org/10.1002/ 2016GL069599

Sheng H, Yang Y, Yang Z et al (2010) The dynamic response of soil respiration to land-use changes in subtropical China. Glob Change Biol 16:1107-1121. https://doi.org/10.1111/j.1365-2486.2009. 01988.x

Singh BP, Cowie AL (2015) Long-term influence of biochar on native organic carbon mineralisation in a low-carbon clayey soil. Sci Rep 4:3687. https://doi.org/10.1038/srep03687

Song X, Yuan H, Kimberley MO, Jiang H, Zhou G, Wang H (2013) Soil $\mathrm{CO} 2$ flux dynamics in the two main plantation forest types in subtropical China. Sci Total Environ 444:363-368. https://doi.org/10. 1016/j.scitotenv.2012.12.006
Song X, Pan G, Zhang C, Zhang L, Wang H (2016) Effects of biochar application on fluxes of three biogenic greenhouse gases: a metaanalysis. Ecosyst Health Sustain 2:e1202. https://doi.org/10.1002/ ehs 2.1202

Spokas KA, Koskinen WC, Baker JM, Reicosky DC (2009) Impacts of woodchip biochar additions on greenhouse gas production and sorption/degradation of two herbicides in a Minnesota soil. Chemosphere 77:574-581. https://doi.org/10.1016/j.chemosphere. 2009.06.053

Thomas SC, Gale N (2015) Biochar and forest restoration: a review and meta-analysis of tree growth responses. New For 46:931-946. https://doi.org/10.1007/s11056-015-9491-7

Vaccari FP, Baronti S, Lugato E, Genesio L, Castaldi S, Fornasier F, Miglietta F (2011) Biochar as a strategy to sequester carbon and increase yield in durum wheat. Eur J Agron 34:231-238. https:// doi.org/10.1016/j.eja.2011.01.006

Van Zwieten L, Kimber S, Morris S et al (2010) Effects of biochar from slow pyrolysis of papermill waste on agronomic performance and soil fertility. Plant Soil 327:235-246. https://doi.org/10.1007/ s11104-009-0050-x

Ventura M, Sorrenti G, Panzacchi P, George E, Tonon G (2013) Biochar reduces short-term nitrate leaching from a horizon in an apple orchard. J Environ Qual 42:76-82. https://doi.org/10.2134/jeq2012. 0250

Wang H, Holden J, Zhang Z, Li M, Li X (2014) Concentration dynamics and biodegradability of dissolved organic matter in wetland soils subjected to experimental warming. Sci Total Environ 470-471: 907-916. https://doi.org/10.1016/j.scitotenv.2013.10.049

Wang J, Xiong Z, Kuzyakov Y (2016) Biochar stability in soil: metaanalysis of decomposition and priming effects. GCB Bioenergy 8: 512-523. https://doi.org/10.1111/gcbb.12266

Wardle DA, Zackrisson O, Nilsson M-C (1998) The charcoal effect in boreal forests: mechanisms and ecological consequences. Oecologia 115:419-426. https://doi.org/10.1007/s004420050536

Wardle DA, Nilsson M-C, Zackrisson O (2008) Fire-derived charcoal causes loss of forest humus. Science 320:629-629. https://doi.org/ $10.1126 /$ science. 1154960

Woolf D (2008) Biochar as a soil amendment: a review of the environmental implications 31

Woolf D, Lehmann J (2012) Modelling the long-term response to positive and negative priming of soil organic carbon by black carbon. Biogeochemistry 111:83-95. https://doi.org/10.1007/s10533-0129764-6

Zackrisson O, Nilsson M-C, Wardle D (1996) Key ecological function of charcoal from wildfire in the boreal forest. Oikos 77:10. https://doi. org $/ 10.2307 / 3545580$

Zhang K, Chen L, Li Y, Brookes PC, Xu J, Luo Y (2017) The effects of combinations of biochar, lime, and organic fertilizer on nitrification and nitrifiers. Biol Fertil Soils 53:77-87. https://doi.org/10.1007/ s00374-016-1154-0

Zhao R, Coles N, Kong Z, Wu J (2015) Effects of aged and fresh biochars on soil acidity under different incubation conditions. Soil Tillage Res 146:133-138

Zhu X et al (2020) Short term effects of biochar on soil CO2 efflux in boreal Scots pine forests. V1. Zenodo repository. [Dataset]. https:// doi.org/10.5281/zenodo.3800097

Zimmerman AR, Gao B, Ahn M-Y (2011) Positive and negative carbon mineralization priming effects among a variety of biochar-amended soils. Soil Biol Biochem 43:1169-1179. https://doi.org/10.1016/j. soilbio.2011.02.005

Publisher's note Springer Nature remains neutral with regard to jurisdictional claims in published maps and institutional affiliations. 


\section{Affiliations}

Xudan Zhu ${ }^{1}\left(\mathbb{D} \cdot\right.$ Tingting Zhu ${ }^{2} \cdot$ Jukka Pumpanen $^{3} \cdot$ Marjo Palviainen $^{4} \cdot$ Xuan Zhou $^{4} \cdot$ Liisa Kulmala $^{4}$. Viktor J. Bruckman ${ }^{5}$. Egle Köster ${ }^{4} \cdot$ Kajar Köster $^{4,6} \cdot$ Heidi Aaltonen $^{4} \cdot$ Naoki Makita $^{4,7} \cdot$ Yixiang Wang $^{2}$. Frank Berninger ${ }^{1}$

1 Department of Environmental and Biological Sciences, University of Eastern Finland, P.O. Box 111, FI-80101 Joensuu, Finland

2 Zhejiang Provincial Key Laboratory of Carbon Cycling and Carbon Sequestration in Forest Ecosystems, Zhejiang A\&F University, Lin'an 311300, China

3 Department of Environmental and Biological Sciences, University of Eastern Finland, P.O. Box 1627, 70211 Kuopio, Finland
Department of Forest Science, University of Helsinki, PO Box 27, 00014 Helsinki, Finland

5 Commission for Interdisciplinary Ecological Studies, Austrian Academy of Sciences (ÖAW), 1010 Vienna, Austria

6 Institute of Forestry and Rural Engineering, Estonian University of Life Sciences, Kreutzwaldi 5, 51014 Tartu, Estonia

7 Department of Environmental Sciences, Shinshu University, Nagano 390-8621, Japan 